\title{
TrkB and TrkC Signaling Are Required for Maturation and Synaptogenesis of Hippocampal Connections
}

\author{
Albert Martínez, ${ }^{1}$ Soledad Alcántara, ${ }^{1}$ Víctor Borrell, ${ }^{1}$ José A. Del Río, ${ }^{1}$ Joan Blasi, ${ }^{2}$ Raquel Otal, ${ }^{1}$ \\ Narciso Campos, ${ }^{3}$ Albert Boronat, ${ }^{3}$ Mariano Barbacid, ${ }^{4,5}$ Inmaculada Silos-Santiago, ${ }^{5,6}$ and Eduardo Soriano ${ }^{1}$ \\ ${ }^{1}$ Department of Animal and Plant Cell Biology, University of Barcelona, Barcelona 08028, Spain, 2Department of Cell \\ Biology and Pathology, University of Barcelona, L'Hospitalet de Llobregat, Barcelona 08907, Spain, ${ }^{3}$ Department of \\ Biochemistry and Molecular Biology, University of Barcelona, Barcelona 08028, Spain, ${ }^{4}$ Centro Nacional de \\ Investigaciones Oncológicas Carlos III, Instituto de Salud Carlos III, 28220 Majalahonda, Madrid, Spain, 5 Department of \\ Molecular Oncology, Bristol-Myers Squibb, Pharmaceutical Research Institute, Princeton, New Jersey 08543-4000, and \\ ${ }^{6}$ Department of Neurobiology, Millennium Pharmaceuticals Inc., Cambridge, Massachusetts 02139-4815
}

Recent studies have suggested a role for neurotrophins in the growth and refinement of neural connections, in dendritic growth, and in activity-dependent adult plasticity. To unravel the role of endogenous neurotrophins in the development of neural connections in the CNS, we studied the ontogeny of hippocampal afferents in trkB (-/-) and trkC (-/-) mice. Injections of lipophilic tracers in the entorhinal cortex and hippocampus of newborn mutant mice showed that the ingrowth of entorhinal and commissural/associational afferents to the hippocampus was not affected by these mutations. Similarly, injections of biocytin in postnatal mutant mice (P10-P16) did not reveal major differences in the topographic patterns of hippocampal connections.

In contrast, quantification of biocytin-filled axons showed that commissural and entorhinal afferents have a reduced number of axon collaterals (21-49\%) and decreased densities of axonal varicosities (8-17\%) in both trkB (-/-) and trkC (-/-) mice. In addition, electron microscopic analyses showed that
trkB (-/-) and trkC (-/-) mice have lower densities of synaptic contacts and important structural alterations of presynaptic boutons, such as decreased density of synaptic vesicles. Finally, immunocytochemical studies revealed a reduced expression of the synaptic-associated proteins responsible for synaptic vesicle exocytosis and neurotransmitter release (v-SNAREs and t-SNAREs), especially in trkB (-I-) mice. We conclude that neither trkB nor trkC genes are essential for the ingrowth or layer-specific targeting of hippocampal connections, although the lack of these receptors results in reduced axonal arborization and synaptic density, which indicates a role for TrkB and TrkC receptors in the developmental regulation of synaptic inputs in the CNS in vivo. The data also suggest that the genes encoding for synaptic proteins may be targets of TrkB and TrkC signaling pathways.

Key words: TrkB receptors; TrkC receptors; neurotrophic factors; mutant mice; neuronal connections; synaptogenesis; synaptic-associated proteins; hippocampus
The neurotrophins, including nerve growth factor (NGF), brainderived neurotrophic factor (BDNF), neurotrophin 3 (NT3), and neurotrophin 4/5 (NT4/5), are essential for the survival of populations of neurons in the PNS and CNS [Jones et al. (1994); Minichiello and Klein (1996); Alcántara et al. (1997); for review, see Snider (1994); Fariñas and Reichardt (1996); Snider and Silos-Santiago (1996)]. Recent studies indicate that neurotrophins may regulate dendritic and axonal growth (Cabelli et al., 1995, 1997; Cohen-Cory and Fraser, 1995; McAllister et al., 1995, 1996, 1997; Bolz et al., 1997; Inoue and Sanes, 1997; Paves and Saarma, 1997) and the efficacy of synaptic transmission (Lohof et al., 1993; Kang and Schuman, 1995; Korte et al., 1995; Thoenen, 1995; Figurov et al., 1996; Prakash et al., 1996; Wang and Poo, 1997).

\footnotetext{
Received April 8, 1998; revised July 1, 1998; accepted July 6, 1998.

This work was supported by grants from Comisión Interministerial de Ciencia y Tecnología, Spain (SAF98-0106), and Dirección General de Investigaciones Científicas y Técnicas (P.M.95-102), and by the Ramón Areces Foundation (Spain), the International Institute for Research in Paraplegia (Switzerland), and the Marato of TV3 to E.S. We thank Robin Rycroft for editorial assistance, and G. Barnstable and R. Jahn for generously providing antibodies to synaptic proteins.

A.M. and S.A. contributed equally to this work.

Correspondence should be addressed to Dr. Eduardo Soriano, Department of Animal and Plant Cell Biology, Faculty of Biology, University of Barcelona, Diagonal 645, Barcelona 08028, Spain.

Copyright (C) 1998 Society for Neuroscience $\quad 0270-6474 / 98 / 187336-15 \$ 05.00 / 0$
}

Moreover, target-derived neurotrophins in the PNS may regulate the maturation of synaptic contacts and the density of synaptic innervation (Miller et al., 1994; Wang et al., 1995; Causing et al., 1997). In addition, a role for BDNF and NT4/5 has been shown for the activity-dependent development of ocular dominance columns in the visual cortex (Cabelli et al., 1995, 1997; Galuske et al., 1996).

Most of the data on the effects of neurotrophins on axonal growth were obtained in vitro or after application of exogenous neurotrophins. To our knowledge, the only study that has analyzed the role of endogenous neurotrophins in the development of neural connections in the CNS was performed by infusion of neurotrophin receptors antagonists (TrkB-IgG) in the visual cortex (Cabelli et al., 1997). To determine the contribution of endogenous neurotrophins to the developmental pattern of neuronal connections and synaptogenesis in the CNS, we studied the ontogeny of the main hippocampal afferents in mice lacking trkB and trkC genes, which encode for the receptors of BDNF and NT4/5, and NT3, respectively (Klein et al., 1991, 1992; Lamballe et al., 1991; Soppet et al., 1991). We chose the hippocampal area not only because neurotrophic factors and their receptors are abundantly expressed in this region (Gall and Isackson, 1989; Ernfors et al., 1990, 1991; Hofer et al., 1990; Gall et al., 1991; 
Isackson et al., 1991; Rocamora et al., 1996), but also because most studies on modulation of synaptic activity by neurotrophins have been performed in this brain area (Kang and Schuman, 1995; Korte et al., 1995; Figurov et al., 1996). In addition, the analysis of the phenotype of hippocampal connections in trkB $(-/-)$ and trkC $(-/-)$ mice allows us to assess the developmental functions of neurotrophins in a region where the main afferent connections are organized both in a layer-specific manner and in a precise topographic order (Amaral and Witter, 1995).

\section{MATERIALS AND METHODS}

Mutant mice. Single-mutant trkB (-/-) and trkC (-/-) mice and doublemutant homozygous mice were generated by mating single and double heterozygous animals (Klein et al., 1993, 1994; Fritzsch et al., 1997). Because no significant differences were observed in the phenotype of wild-type and heterozygous littermates, both groups of mice were used as controls for the quantitative analyses.

In situ hybridization. Embryonic day (E14, E16, E18), postnatal day (P0, P5, P10, P15, P21), and adult mice (NMRI strain; Iffa Credo, Lyon, France) were perfused with $4 \%$ paraformaldehyde in $0.1 \mathrm{~m}$ phosphate buffer, cryoprotected in $30 \%$ sucrose, and frozen. Coronal sections (30-50 $\mu \mathrm{m}$ thick) were obtained and hybridized as described elsewhere (Lecea et al., 1995, 1997). Briefly, sections were deproteinized with $0.2 \mathrm{~N}$ $\mathrm{HCl}$ for $10 \mathrm{~min}$, acetylated with $0.25 \%$ acetic anhydride in $0.1 \mathrm{M}$ triethanolamine buffer, $\mathrm{pH} 8.0$, and post-fixed for $10 \mathrm{~min}$ in $4 \%$ paraformaldehyde. Sections were then hybridized overnight at $60^{\circ} \mathrm{C}$ with digoxigenin-labeled antisense RNA probes to mouse BDNF and NT3 and to the tyrosine kinase domains of mouse TrkB and TrkC in a solution containing 50\% formamide, $20 \mathrm{~mm}$ PIPES, $5 \times$ Denhardt's solution, $10 \%$ dextran sulfate, $250 \mu \mathrm{g} / \mathrm{ml}$ yeast tRNA, $250 \mu \mathrm{g} / \mathrm{ml}$ salmon sperm DNA, $50 \mathrm{~mm}$ dithiothreitol, $0.62 \mathrm{M} \mathrm{NaCl}$, and $10 \mathrm{~mm}$ EDTA solution. Sections were then digested with RNase A $\left(37^{\circ} \mathrm{C}\right.$ for $\left.1 \mathrm{hr}\right)$ and washed in $0.5 \times \mathrm{SSC}$ plus $50 \%$ formamide $\left(55^{\circ} \mathrm{C}\right)$ and in $0.1 \times \mathrm{SSC}$ plus $0.5 \%$ sarcosyl $\left(60^{\circ} \mathrm{C}\right)$. After hybridization, sections were blocked with $10 \%$ sheep normal serum ( $2 \mathrm{hr}$ ), incubated overnight with an alkaline phosphatase-labeled antidigoxigenin antibody (1:2000), and developed with a 5-bromo-4-chloro3 -idolyl phosphate (BCIP) and nitroblue tetrazolium (NBT) substrate. After several washes, sections were mounted onto slides and coverslipped with Mowiol. Sections hybridized with sense riboprobes did not give signals above background levels.

Anterograde tracing. Newborn and P5 mice were perfused with $4 \%$ paraformaldehyde in phosphate buffer, and their brains were dissected out. Crystals of $1-1^{\prime}$-dioctadecyl-3,3,3',3'-tetramethylindocarbocyanine perchlorate (DiI) were injected into the entorhinal area or hippocampus as described (Supèr and Soriano, 1994). Brains were stored in phosphatebuffered $4 \%$ paraformaldehyde for 5-8 weeks in the dark at room temperature. Coronal sections were obtained with a vibratome, counterstained with the DNA-specific dye bisbenzimide, and mounted with an antifading mounting medium. The sections were analyzed and photodocumented in a Polyvar (Reichert) microscope equipped with fluorescent filters. P10-P16 mice were injected by iontophoresis of biocytin ( $20 \mathrm{~min}$; positive current; $7 \mathrm{sec}$ on/off cycle) in the entorhinal cortex or the hippocampus. After $24 \mathrm{hr}$ of survival, animals were perfused with $4 \%$ paraformaldehyde, and brains were post-fixed in the same fixative and sectioned at $50 \mu \mathrm{m}$ using a vibratome. Free-floating sections were then incubated with the avidin-biotin-peroxidase complex (ABC) (Vector Labs, Burlingame, CA), developed with $0.05 \%$ diaminobenzidine (DAB) and $0.01 \%$ hydrogen peroxide in the presence of $0.02 \%$ nickel sulfate (Del Río et al., 1997), and counterstained with cresyl violet. A total of 97 postnatal mice were used $(n=11 \operatorname{trkB}(+/+), 24 \operatorname{trkB}( \pm), 23 \operatorname{trkB}(-/-)$, $11 \operatorname{trk} \mathrm{C}(+/+), 16 \operatorname{trk} \mathrm{C}( \pm), 12 \operatorname{trk} \mathrm{C}(-/-))$. Five newborn double-mutant $\operatorname{trkB}(-/-) /$ trkC $(-/-)$ mice were also injected with DiI. Selected entorhinal and commissural fibers from trkB $(-/-)$ and trk $\mathrm{C}(-/-)$ mice (P13-P14) and from control littermates were drawn using a $40 \times$ oilimmersion objective lens ( $n=2-4$ animals per group, 32-58 fibers). Length of fibers was measured using a planimeter, and the branching index (Del Río et al., 1997) and density of axonal varicosities (number of varicosities per $100 \mu \mathrm{m}$ ) were calculated. Statistical analysis was performed using the Student's $t$ test.

Electron microscopy. trkB $(-/-)(\mathrm{P} 13, n=2), \operatorname{trk} \mathrm{C}(-/-)(\mathrm{P} 12-13, n=$ $3)$, and control littermates $[\operatorname{trk} \mathrm{B}(+/+), n=1 ; \operatorname{trkB}(+/-), n=1 ;$ trkC $(+/+), n=1 ; \operatorname{trkC}(+/-), n=2]$ were perfused with $2 \%$ glutaraldehyde- $-1 \%$ paraformaldehyde in $0.12 \mathrm{M}$ phosphate buffer. Brains were removed from the skull and fixed in the same solution overnight. Tissue slices were post-fixed with $2 \%$ osmium tetroxide, stained with $2 \%$ uranyl acetate, and embedded in Araldite. Ultrathin sections were collected onto formvar-coated slot grids and stained with lead citrate. Electron micrographs covering $100 \mu \mathrm{m}^{2}$ (final magnification $19,000 \times$ ) were randomly taken from each hippocampal layer, and the number of synaptic contacts was counted ( $n=30-31$ micrographs for each layer and group). For the morphometric analysis of presynaptic boutons and synapses, randomly selected synaptic contacts were micrographed at 58,000× final magnification $(n=81-170$ axon terminals and synapses per group and layer). The total number of synaptic vesicles and vesicles clustered near the active zone [whose membrane was closer than $50 \mathrm{~nm}$ (Rosahl et al., 1995)] was counted. The area of axon terminals and the length and thickness of synaptic specializations were calculated using the IMAT image analysis program (Scientific-Technical Services, University of Barcelona). Statistical analysis was performed using the Student's $t$ test.

Organotypic slice cultures. Entorhinohippocampal cocultures and hippocampus/hippocampus cocultures were prepared from newborn trkB $(-/-)$, trkC $(-/-)$, and double-mutant trkB $(-/-) /$ trk $\mathrm{C}(-/-)$ mice, as well as from control littermates as described (Del Río et al., 1997). Animals were anesthetized by hypothermia, their brains were removed, and the hippocampus and entorhinal cortex were dissected out under a microscope. Horizontal sections (350 $\mu \mathrm{m}$ thick) were obtained using a McIlwain tissue chopper. Selected slices were cocultured using the interphase membrane method (Stoppini et al., 1991). A total of 52 entorhinohippocampal and 50 hippocampus/hippocampus mixed slice cocultures of mutant and control mice were prepared. In addition, cultures from single-mutant mice were also prepared $(n=38)$. A crystal of biocytin was placed in the entorhinal cortex or the hippocampus $24 \mathrm{hr}$ before fixation. Cocultures were fixed with $4 \%$ paraformaldehyde after 9-15 d in vitro (DIV). Horizontal sections (40 $\mu \mathrm{m}$ thick) were obtained, incubated with the ABC complex, and developed with diaminobenzidine/ nickel and hydrogen peroxide as described above. Cultures were then counterstained with cresyl violet and coverslipped.

Immunocytochemistry and immunoblot. Mutant and control littermates $(\mathrm{P} 13 ; \operatorname{trk} \mathrm{B}(-/-), n=2, \operatorname{trkB}(+/+), n=1 ; \operatorname{trkB}(+/-), n=1 ; \operatorname{trkC}$ $(-/-), n=2 ; \operatorname{trkC}(+/+), n=1 ; \operatorname{trkC}(+/-), n=1)$ were perfused with $4 \%$ paraformaldehyde in PBS, cryoprotected in $30 \%$ sucrose, and sectioned at $25 \mu \mathrm{m}$. Sections from mutant and control mice were processed in bulk. Free-floating sections were blocked with $15 \%$ fetal bovine serum solution and incubated overnight at $4{ }^{\circ} \mathrm{C}$ with one of the following primary antibodies (diluted 1:1000-1500): anti- $\alpha$-tubulin (Sigma, Poole Dorset, UK), anti-synapsin I [MAB 355, Chemicon, Temecula, CA (recognizing the C-terminal fragment of synapsin I)], anti-synaptophysin (MAB SVP-38, Sigma), anti-synaptotagmin I [MAB 41.1, gift from R. Jahn (Göttingen, Germany) (Brose et al., 1992)], anti-SNAP-25 (MAB SMI 81, Sternberger-Meyer, Jarrettsville, MD), anti-synaptobrevin 2 [MAB 69.1, gift from R. Jahn (Edelmann et al., 1995)], anti-syntaxin 1 [MAB HPC-1 recognizing isoforms $1 \mathrm{~A}$ and $1 \mathrm{~B}$; gift from $\mathrm{G}$. Barnstable (New Haven, CT) (Barnstable et al., 1985)], and anti-Rab3a [MAB 42.2, gift from R. Jahn (Matteoli et al., 1991)]. Thereafter, sections were incubated for $3 \mathrm{hr}$ at room temperature in the dark with FITCconjugated secondary antibodies, mounted onto slides, and coverslipped with an antifading mounting medium. Sections were viewed in a Leica TCS 4D confocal scanning laser microscope. Two serial confocal images, $2 \mu \mathrm{m}$ apart, from each example were used to quantify the fluorescence intensity of synaptic-associated protein immunolabeling. The intensities of fluorescence (expressed as gray levels) were measured along vertical strips extending from the stratum oriens to the hilar region, with the aid of the IMAT image analysis program. Continuous linear profiles from control and null-mutant mice were then averaged, and the fluorescence intensities were calculated for each hippocampal layer. Statistical analysis was performed using the Student's $t$ test.

The forebrains of two $t r k \mathrm{~B}(-/-)$ and trkC $(-/-)$ mice and littermate controls were frozen and homogenized in $\mathrm{HEPES} / \mathrm{NaOH} 10 \mathrm{~mm}, \mathrm{pH} 7.4$, containing $0.32 \mathrm{M}$ sucrose, $1 \mu \mathrm{g} / \mathrm{ml}$ leupeptin, $5 \mu \mathrm{g} / \mathrm{ml}$ aprotinin, $1 \mathrm{~mm}$ PMSF, and $1 \mathrm{~mm}$ EGTA. To remove nuclei and cellular debris, the homogenates were centrifuged at $2000 \mathrm{rpm}$ in a Beckman JA21 rotor for $2 \mathrm{~min}$ followed by $12,000 \mathrm{rpm}$ for $11 \mathrm{~min}$ in the same rotor. Supernatants containing cytosolic and light membrane fractions were subjected to SDS-PAGE and immunoblot analysis using $10 \mu \mathrm{g}$ of protein per lane. Gels were then electrotransferred to nitrocellulose membranes using a semi-dry blotting system. Nitrocellulose membranes were blocked with $5 \%$ nonfat milk in TBS $(140 \mathrm{~mm} \mathrm{NaCl}, 10 \mathrm{~mm}$ Tris/ $\mathrm{HCl}, \mathrm{pH} 7.4$, with $0.1 \%$ Tween-20) for $30 \mathrm{~min}$ at room temperature and incubated over- 
night with the monoclonal antibodies described above. After several washes, membranes were incubated with peroxidase-conjugated antimouse antibodies for $1 \mathrm{hr}$ at room temperature and developed using the ECL method (Amersham, Bucks, UK), placed in contact with x-ray films for 10-60 sec, and quantified (Phoretix 1D Gel Analysis system). The values were normalized to $\alpha$-tubulin to correct for possible inequalities in protein content.

\section{RESULTS}

\section{Expression of neurotrophic factors and their receptors in the developing hippocampal region}

In the mouse, developing entorhinal afferents reach the hippocampus at embryonic day 15 (E15) and invade the appropriate target layer (stratum lacunosum-moleculare) by E16, whereas commissural/associational afferents reach the target layers (stratum oriens and stratum radiatum) 2-3 d later (Supèr and Soriano, 1994; Supèr et al., 1998). To investigate the role of neurotrophins and their receptors in the development of these principal hippocampal connections, we first analyzed the developmental expression of $t r k \mathrm{~B}, t r k \mathrm{C}, b d n f$, and $n t 3$ genes. At embryonic stages (E14-E18), both TrkB and TrkC mRNAs were detected in postmitotic neurons of the entorhinal cortex, in the pyramidal neurons of the hippocampus proper (CA1-CA4 subfields), and in the granule cells of the dentate gyrus. At postnatal stages (P0-P15), when hippocampal connections mature, levels of expression for both transcripts increased steadily and were maximal (Fig. 1A,B). mRNA hybridization signals decreased to adult-like levels by P21. BDNF mRNA was also widely expressed in the entorhinohippocampal system at all ages (Fig. $1 C$ ), with levels of expression increasing from P5 on to reach maximal expression levels in the adult. NT3 transcripts, which in the adult hippocampus are restricted to the dentate gyrus and the CA2 region (Ernfors et al., 1990; Lindvall et al., 1992; Isackson, 1995), were upregulated at prenatal and early postnatal stages and were expressed in most neurons within the hippocampus and entorhinal areas (data not shown). No remarkable differences in the pattern of expression for either transcript were observed between the medial and lateral fields of the entorhinal cortex. These results show that TrkB and TrkC receptors and their ligands, BDNF and NT3, are expressed in the hippocampal region at the time of ingrowth and development of the main hippocampal afferents (Supèr and Soriano, 1994; Del Río et al., 1997; Supèr et al., 1998). Furthermore, TrkB and TrkC receptors are expressed in entorhinohippocampal projection cells and in the neurons of the CA3 subfield that give rise to the commissural/associational pathway (Amaral and Witter, 1995).

\section{Pattern of hippocampal connectivity in trkB (-/-) and trkC (-/-) mice}

Recently, it has been suggested that neurotrophins may be involved in the attraction of the axonal growth cone (Paves and Saarma, 1997; Song et al., 1997). To test whether TrkB or TrkC signaling is required for the ingrowth and targeting of afferent fibers in the hippocampal region we next examined the development of hippocampal connections in trkB (-/-) and trkC $(-/-)$ mice. Injections of the anterograde tracer DiI in the entorhinal area at $\mathrm{P} 0-\mathrm{P} 5$ showed that in $\operatorname{trk} \mathrm{B}(-/-)$ and $\operatorname{trk} \mathrm{C}(-/-)$ mice
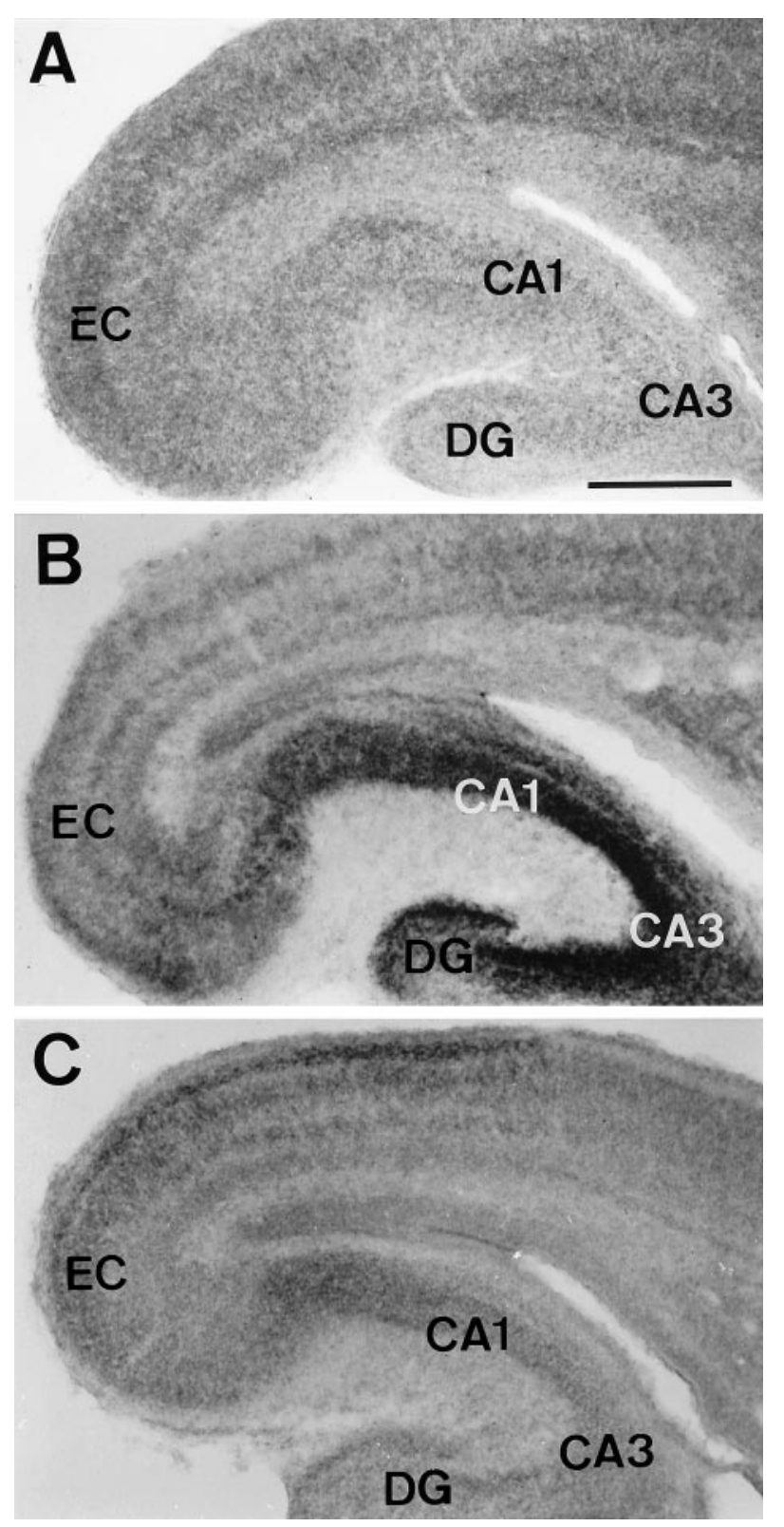

Figure 1. Expression of $\operatorname{TrkB}(A), \operatorname{TrkC}(B)$, and $\operatorname{BDNF}(C)$ mRNAs in horizontal sections of $\mathrm{P} 0$ mice. Positive neurons are widely distributed throughout the hippocampus $(C A 1, C A 3)$, the dentate gyrus $(D G)$, and the entorhinal cortex $(E C)$. Scale bars: $A-C, 300 \mu \mathrm{m}$.

entorhinal axons innervated the appropriate target layers, the stratum lacunosum-moleculare, and the dentate molecular layer, with a pattern indistinguishable from that of wild-type and heterozygous littermates (control mice) (Fig. 2A-C). Similarly, tracer injections in the hippocampus of $\operatorname{trk} \mathrm{B}(-/-)$ and $t r k \mathrm{C}$ $(-/-)$ mice at $\mathrm{P} 0-\mathrm{P} 5$ resulted in a large number of commissural fibers in the contralateral hippocampus innervating the stratum

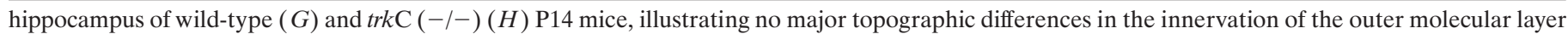

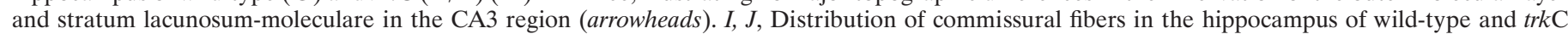

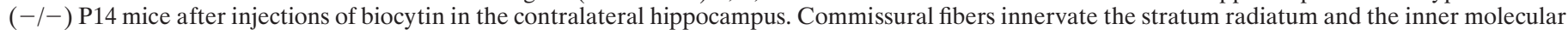

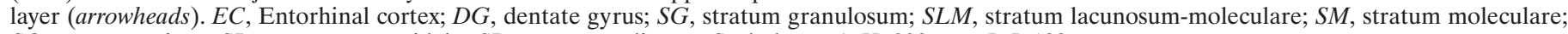
$S O$, stratum oriens; $S P$, stratum pyramidale; $S R$, stratum radiatum. Scale bars: $A-H, 300 \mu \mathrm{m} ; I, J, 100 \mu \mathrm{m}$. 

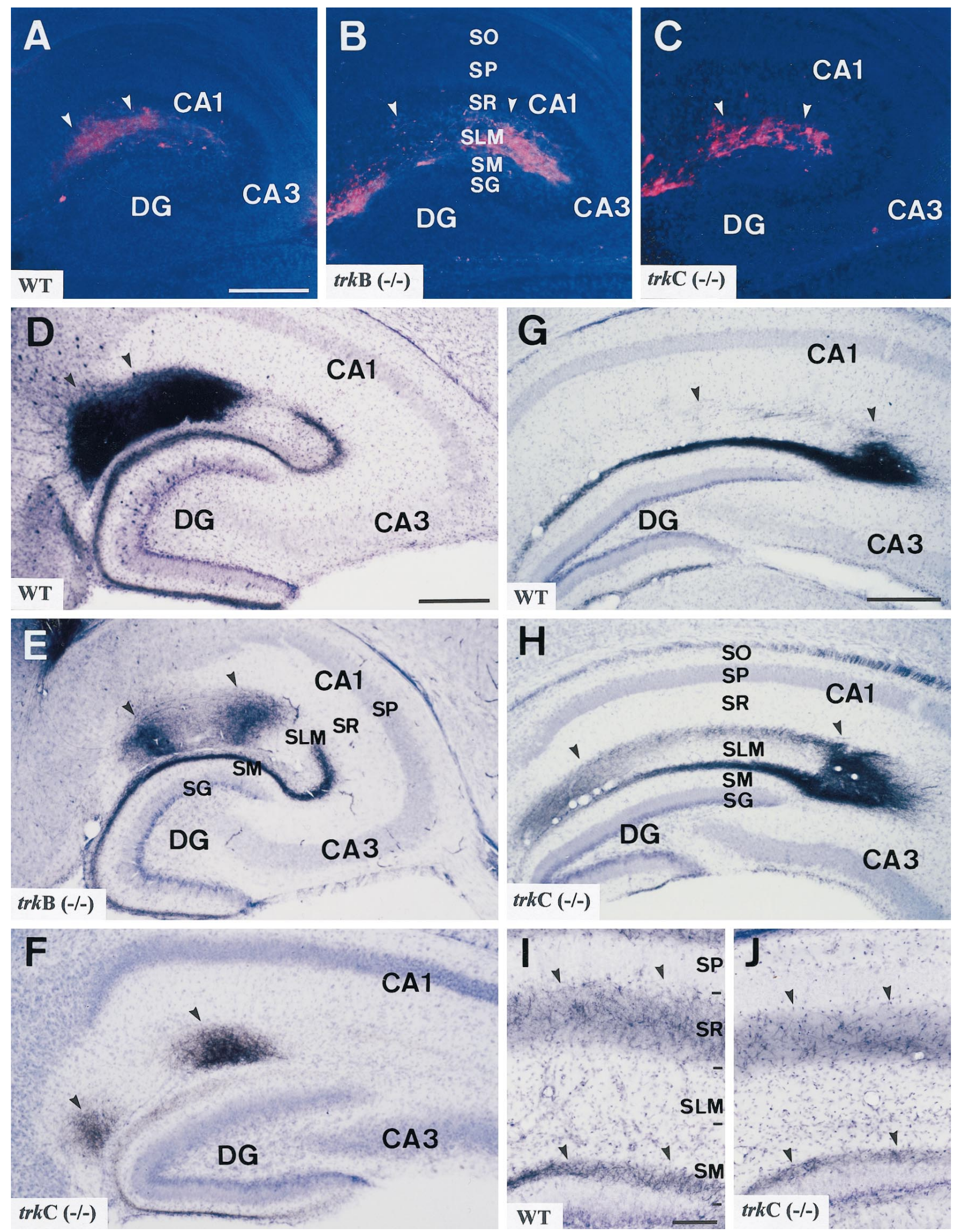

Figure 2. Distribution of entorhinohippocampal and commissural projections in trkB and trkC $(-/-)$ mice. $A-C$, Distribution of entorhinohippocampal afferents in wild-type $(A), \operatorname{trkB}(-/-)(B)$, and trkC $(-/-)(C)$ newborn mice after injections of DiI in the entorhinal cortex. Labeled fibers (arrowheads) are observed running in the stratum lacunosum-moleculare and in the white matter in all three animal groups. Sections are counterstained with bisbenzimide. $D-F$, Pattern of medial entorhinal projections in wild-type $(D)$, trkB $(-/-)(E)$, and trkC $(-/-)(F)$ P14 mice after iontophoresis of biocytin in the entorhinal cortex. In all three groups, axons innervate the middle tier of the molecular layer and two patches in the stratum moleculare, in the CA2/CA1 and CA1/subiculum interphase (arrowheads). G, H, Distribution of lateral entorhinal projections in the (Figure legend continues) 
oriens and stratum radiatum, which are the normal layers of termination for these fibers (data not shown).

At later stages (P10-P16) the topography of lateral and medial entorhinal projections in wild-type mice displayed adult-like patterns of innervation, with distinct axons terminating in different hippocampal subdivisions and sublayers (Amaral and Witter, 1995). Thus, medial entorhinal projections innervated the middle tier of the dentate molecular layer and the stratum lacunosummoleculare, where fibers formed two patches of higher innervation in the subiculum and CA1 (Fig. 2D). Conversely, lateral entorhinal projections terminated in the outer tier of the dentate molecular layer and in the stratum lacunosum-moleculare of the $\mathrm{CA} 3 / \mathrm{CA} 2$ region and $\mathrm{CA} 1 /$ subicular interphase (Fig. $2 G$ ). In trkB $(-/-)$ and trkC $(-/-)$ mice, entorhinal afferents terminated in well defined region-specific patches and sublayers indistinguishable from those in wild-type mice in both the hippocampus proper and the dentate gyrus (Fig. 2E,F,H).

Similarly, commissural afferents in these homozygous mutant mice were targeted correctly to the stratum radiatum and stratum oriens in the hippocampus proper and to the inner molecular layer in the dentate gyrus (Fig. 2I,J). No aberrant innervation or axonal trajectories were noted in these mutant mice. These findings indicate that neither TrkB nor TrkC signaling is required for the ingrowth of hippocampal afferents. Furthermore, the data indicate that these receptors are not essential for the layer-specific or region-specific targeting of hippocampal connections.

\section{Reduced axonal elaboration in trkB (-/-) and trkC $(-/-)$ mice}

The injections of tracers in newborn and late postnatal mice frequently resulted in a sparse innervation of the hippocampus in trkB (-/-) and trkC (-/-) mice when compared with wild-type littermates. To examine the possibility that $t r k \mathrm{~B}$ and $t r k \mathrm{C}$ genes may regulate the maturation and elaboration of hippocampal connections, we quantified the branching pattern of single, biocytin-filled axons in P10-P16 mutant and control mice. This analysis showed that entorhinal and commissural fibers had fewer axon collaterals in both $\operatorname{trkB}(-/-)$ and $\operatorname{trk} \mathrm{C}(-/-)$ mice in the hippocampus proper (CA1 and $\mathrm{CA} 3$ regions) and the dentate gyrus (Fig. 3). In trkC (-/-) mice, this reduction was dramatic for commissural and entorhinal axons innervating all the hippocampal subregions (37-49\%), except for entorhinal afferents present in CA1 subfield $(26 \%)$. In contrast, trkB $(-/-)$ mice showed a $20-36 \%$ reduction in the branching index of single axons, which was more conspicuous for the commissural fibers innervating the hippocampus proper. These findings indicate that TrkB and TrkC receptors may regulate the elaboration and complexity of hippocampal afferents.

We next estimated the number of putative presynaptic boutons formed by $\operatorname{trk} \mathrm{B}(-/-)$ and $t r k \mathrm{C}(-/-)$ axons by calculating the density of axonal varicosities present along biocytin-labeled fibers. In both trkB $(-/-)$ and trkC $(-/-)$ mice, commissural and entorhinal afferents displayed significantly reduced densities of axonal varicosities $(8-17 \%)$, with the exception of commissural fibers in the $\mathrm{CA} 3$ region of $\operatorname{trk} \mathrm{C}(-/-)$ mice (Fig. 3).

\section{Phenotype of hippocampal connections in trkB (-/-)/ trkC (-/-) mice}

The above observations showed relatively mild alterations in the topography of hippocampal afferents in trkB $(-/-)$ and trk $\mathrm{C}$ $(-/-)$ mice. To determine whether these findings may be attributable to redundancy of neurotrophin receptors, we generated double-mutant trkB (-/-)/trkC $(-/-)$ mice. Injections of DiI in the entorhinal cortex and hippocampus of double-mutant newborn mice did not reveal major differences in the pattern of connections compared with control littermates or single homozygous mutant mice (data not shown).

trkB $(-/-) /$ trk C $(-/-)$ animals die soon after birth (Minichiello and Klein, 1996; Silos-Santiago et al., 1997). To analyze the maturation of hippocampal connections in these mice, we reconstituted the entorhinohippocampal and commissural projections in organotypic slice cocultures (Del Río et al., 1997) of newborn trkB (-/-)/trkC (-/-) mice, which allowed us to monitor the development of hippocampal afferents for up to $15 \mathrm{~d}$ in vitro. The hippocampal projections develop in slice cocultures with laminar and topographic specificity similar to that in vivo (Frotscher and Heimrich, 1993; Li et al., 1993; Del Río et al., 1997). Thus, entorhinal afferents densely innervate the stratum lacunosum-moleculare and the outer molecular layer in the dentate gyrus in cocultures from wild-type mice (Fig. 4A). A similar pattern of entorhinal termination was observed in single trkB $(-/-)$ or trkC $(-/-)$ cocultures (data not shown), which is consistent with the above observations in vivo.

In $\operatorname{trkB}(-/-) /$ trk $\mathrm{C}(-/-)$ slice cocultures, the entorhinohippocampal pathway developed with correct layer specificity (Fig. $4 B$ ) but with sparse innervation, which led to a narrower afferent termination zone $(84.28 \pm 13.20 \mu \mathrm{m} ; n=3, p<0.01)$ than in wild-type $(161.25 \pm 8.35 \mu \mathrm{m} ; n=29)$ and single-mutant cultures $[139.33 \pm 7.56 \mu \mathrm{m} ; n=23, \operatorname{trkB}(-/-) ; 159.00 \pm 7.59 \mu \mathrm{m} ; n=15$, trkC $(-/-)]$. In addition, the patchy, region-specific distribution of fibers in the stratum lacunosum-moleculare was less clearly discernible in these trkB $(-/-) /$ trkC $(-/-)$ cultures. These findings show that hippocampal connections develop even in the absence of both TrkB and TrkC receptors but form less elaborate innervations. This suggests a partial compensation of TrkB and TrkC receptors in the normal development of hippocampal connections.

\section{Analyses of mixed organotypic slice cocultures}

Although neurotrophins are primarily considered to act as retrograde factors derived from target neurons, recent investigations indicate that neurotrophic factors may also act in an autocrine manner or even like anterograde factors released by nerve terminals (Davies, 1996; Von Bartheld et al., 1996; Altar et al., 1997; Liu et al., 1997; Tonra et al., 1998).

The organotypic slice approach also allowed us to prepare mixed slice cocultures of double-mutant and wild-type mice to determine the role of neurotrophin receptors present in afferent (entorhinal) and target (hippocampal) neurons. When wild-type entorhinal slices were cocultured with double-mutant hippocampus, the pattern of entorhinal innervation was similar to that of control cocultures (Fig. $4 C$ ) (termination zone $=147.86 \pm 10.47$ $\mu \mathrm{m} ; n=8)$. In contrast, trkB $(-/-) /$ trkC $(-/-)$ entorhinal slices cocultured with wild-type hippocampus (Fig. 4D) resulted in a reduced zone of innervation $(92.73 \pm 11.76 \mu \mathrm{m} ; n=12, p<0.01)$ reminiscent of that of double-mutant cocultures (Fig. $4 B$ ). These data indicate that abnormalities in hippocampal innervation are caused by the lack of TrkB and TrkC receptors in the afferent entorhinal neurons, with little contribution of the receptors present in the target hippocampal neurons.

\section{trkB (-/-) and trkC (-/-) mice show decreased synaptic innervation}

The morphometric analysis of single axons has shown that the number of axonal branches and varicosities is reduced in these 


\section{BRANCHING INDEX}

\section{ENTORHINAL FIBERS}
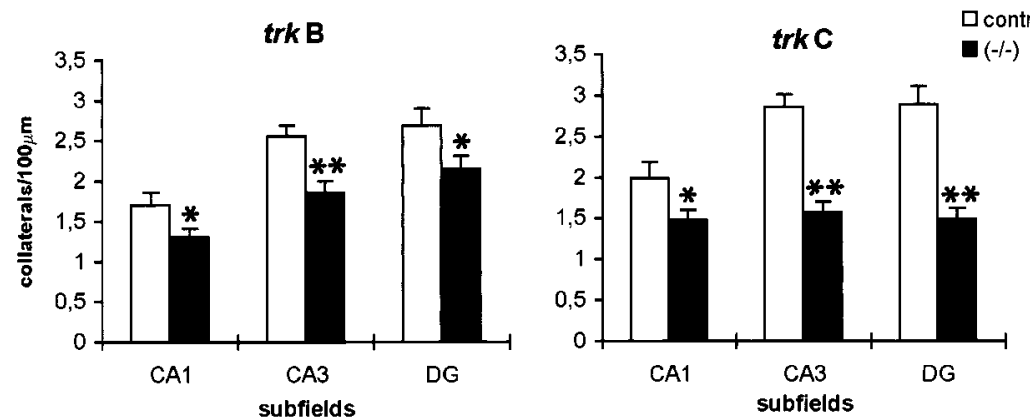

\section{COMMISSURAL FIBERS}
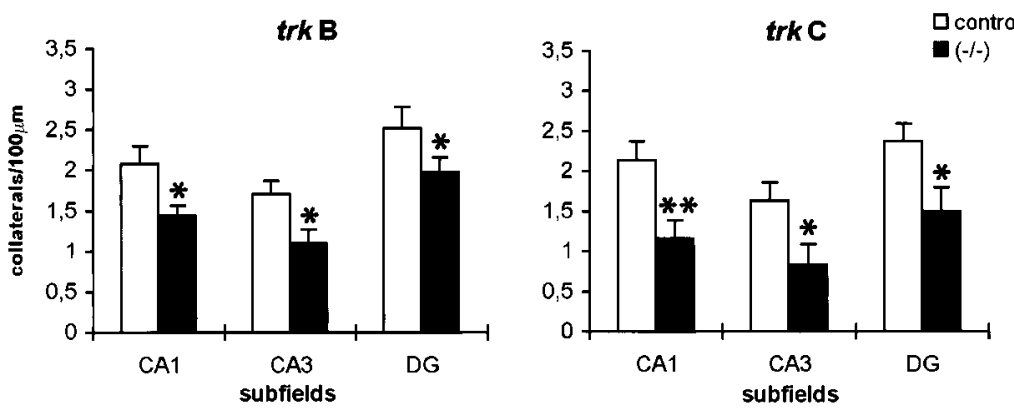

\section{DENSITY OF BOUTONS}

\section{ENTORHINAL FIBERS}
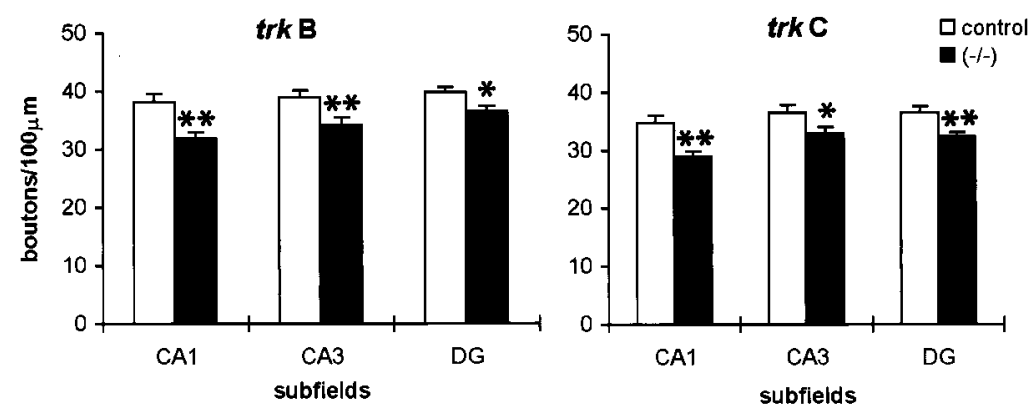

\section{COMMISSURAL FIBERS}
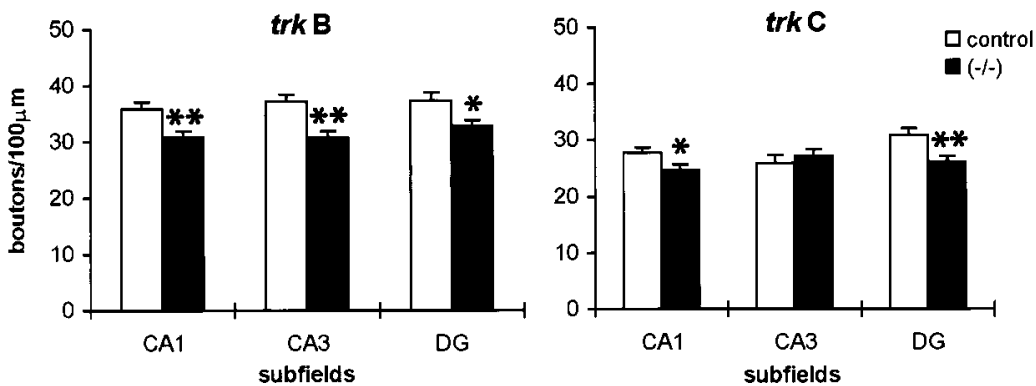

Figure 3. Branching index (number of branching points/100 $\mu \mathrm{m}$ ) and density of boutons (number of boutons $/ 100 \mathrm{~mm}$ of fiber) of commissural and entorhinal axons in trkB (-/-) mice, trkC $(-/-)$ mice, and control littermates (P12-P14 mean \pm SEM). There are significant differences between control and mutant mice $\left({ }^{*} p<0.05 ;{ }^{* *} p<0.01\right.$; Student's $t$ test). Abbreviations as in Figure 2.

homozygous mutant mice. To determine whether the decrease in axonal branching is accompanied by changes in synaptogenesis, we performed a quantitative electron microscopic study in P12$\mathrm{P} 13$ mice. Axon terminals in hippocampal plexiform layers in trkB
$(-/-)$ and trkC $(-/-)$ mice established synaptic contacts with normal postsynaptic elements such as dendritic shafts and spines (Fig. 5A-C). However, the density of synaptic contacts in homozygous mutants was lower in all hippocampal layers of entorhinal 

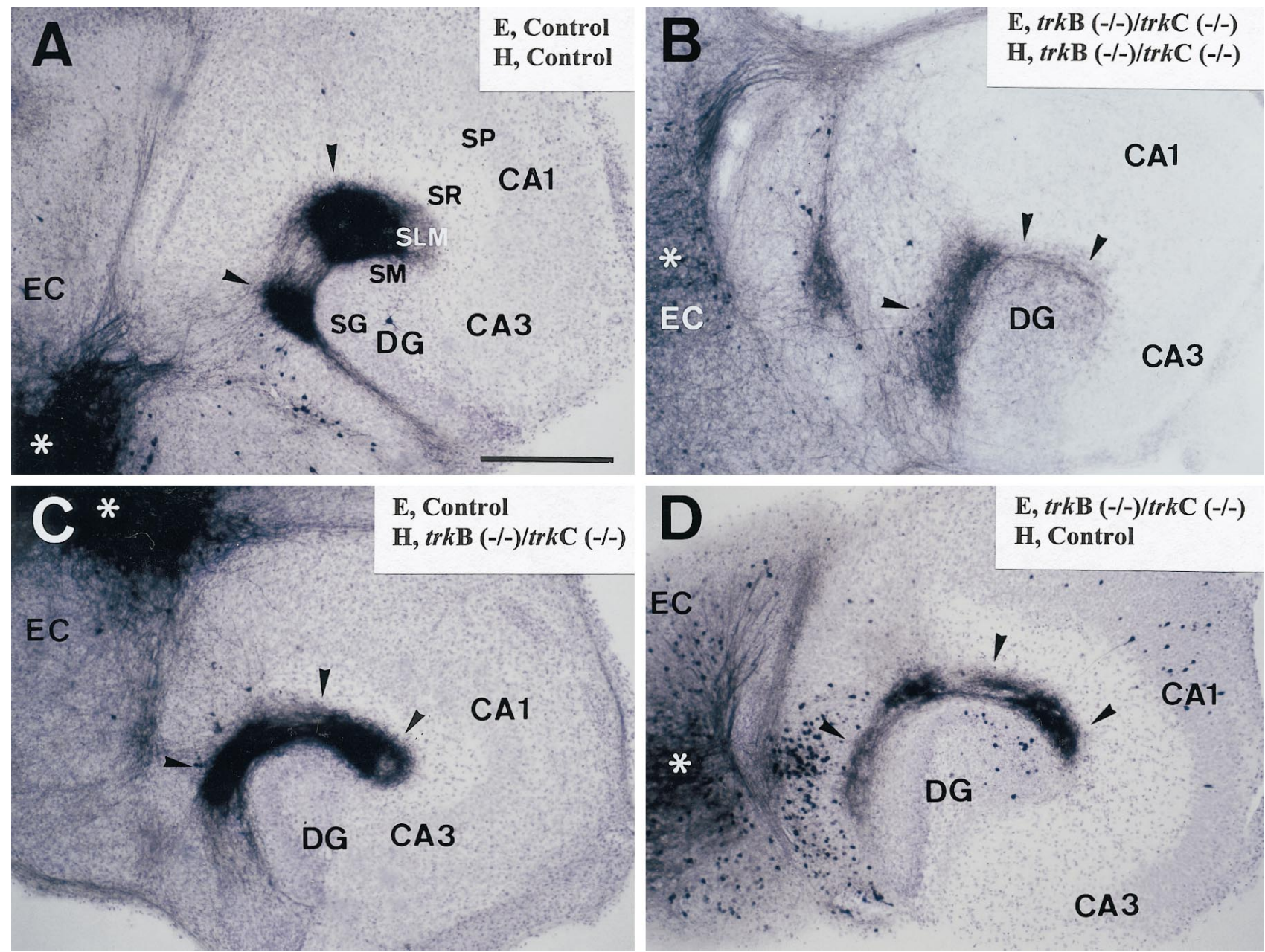

Figure 4. Formation of entorhinohippocampal connections in organotypic slice cocultures of newborn double-mutant trkB $(-/-) /$ trkC $(-/-)$ mice after 15 DIV. Control cocultures $(A)$ and control entorhinal slices cocultured with trkB $(-/-) /$ trkC $(-/-)$ hippocampus $(C)$ resulted in a normal pattern of innervation with fibers terminating into a thick zone covering the stratum lacunosum-moleculare and the molecular layer. In contrast, trkB $(-/-) /$ trkC $(-/-)$ cocultures $(B)$ and double-mutant entorhinal cortex cocultured with control hippocampus $(D)$ resulted in a thinner layer of termination of entorhinal fibers. Injection sites of the culture are indicated with asterisks. Arrowheads point to labeled entorhinal fibers. Abbreviations as in Figure 2. Scale bar, $300 \mu \mathrm{m}$.

and commissural afferent termination. This decrease in synaptic innervation, compared with control littermates, was more dramatic in trkB (-/-) mice (17-39\%) than in trk $\mathrm{C}(-/-)$ animals $(11-17 \%)$ (Fig. 5D). In addition, particularly in trkB (-/-) mice, differences were more dramatic in the hippocampus proper (36$39 \%$ reduction in the stratum radiatum and stratum lacunosummoleculare, respectively) than in the molecular layer of the dentate gyrus. These results show that the lack of TrkB and TrkC signaling alters synaptogenesis in the CNS by regulating the number of the synaptic inputs.

\section{Fine structural abnormalities of axon terminals in trkB $(-/-)$ and trkC (-I-) mice}

To discern whether the remaining synaptic boutons may be affected by the absence of TrkB or TrkC receptors, a detailed fine structural analysis was performed. We observed that the majority of axon terminals appeared to display a low density of synaptic vesicles, which were distributed homogeneously throughout the axonal profile in the homozygous mutant mice. Furthermore, there was little clustering of synaptic vesicles near the active synaptic zone (Fig. 5E,F). These abnormalities were more dramatic in $t r k \mathrm{~B}(-/-)$ than in trk $\mathrm{C}(-/-)$ mice. In addition, synaptic specializations were less conspicuous in these homozygous mutant mice.

To substantiate these observations we performed a morphometric study of presynaptic boutons and synaptic contacts in the different termination layers of the hippocampus (Table 1; Fig. $5 E, F)$. Within all the termination fields, presynaptic boutons were larger in trkB (-/-) mice (28-38\%) and displayed a lower density of synaptic vesicles $(19-41 \%)$ than in control littermates. In contrast, no significant differences for these parameters were observed in trkC $(-/-)$ animals. In addition, the number of synaptic vesicles clustered near the active zone (Rosahl et al., 1995) was much lower in both trkB (-/-) (19-40\%) and trkC $(-/-)(23-30 \%)$ mice (Table 1; Fig. $5 F)$ than in their control littermates. Moreover, the thickness of the postsynaptic zone was reduced in both homozygous mutants, whereas the synaptic cleft was slightly thinner only in $\operatorname{trk} \mathrm{B}(-/-)$ mice. Finally, we did not find significant differences in the length of synaptic contacts in trkB $(-/-)$ and trkC $(-/-)$ mice (Table 1$)$. These findings were 


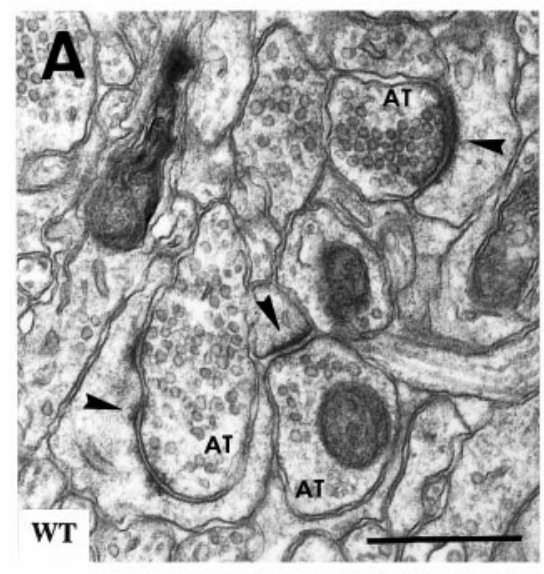

D
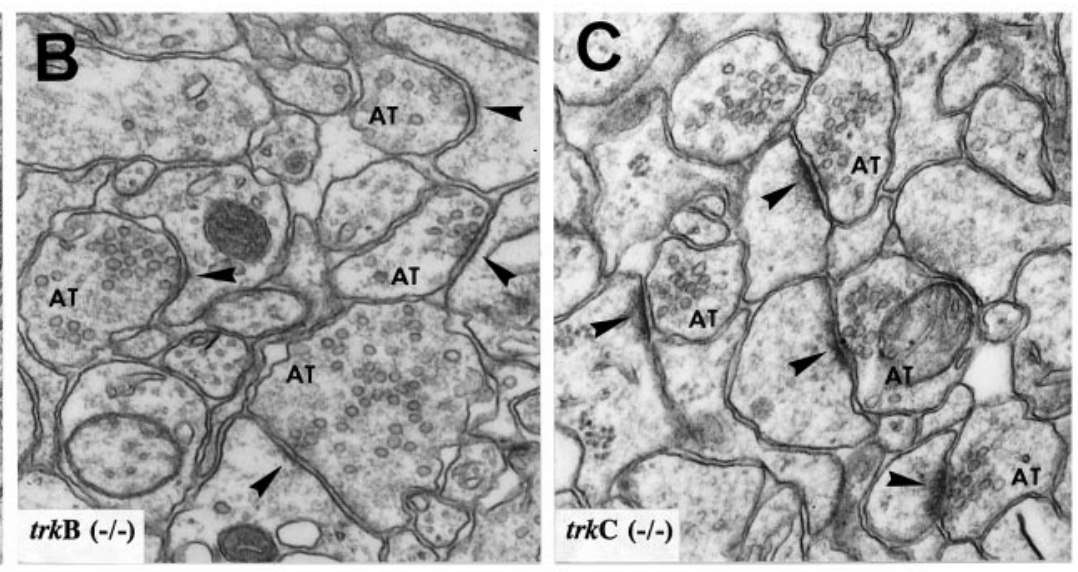

DENSITY OF SYNAPSES
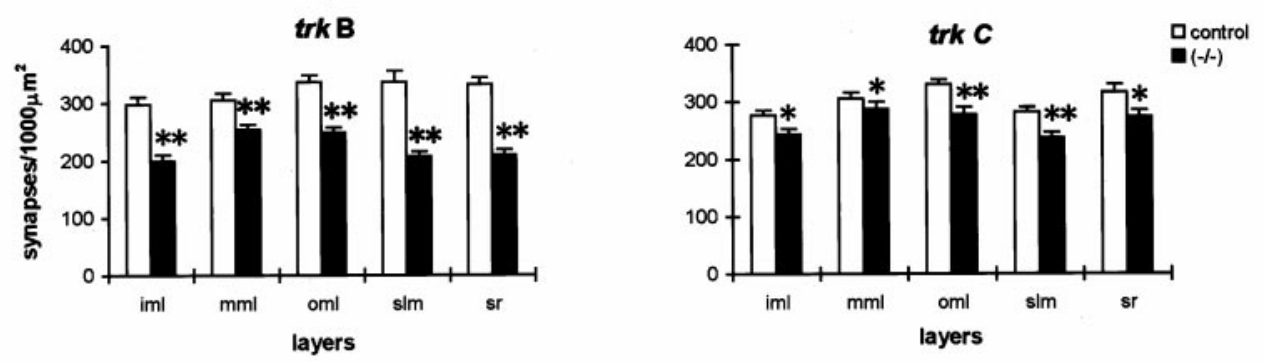

$\mathbf{E}$

DENSITY OF SYNAPTIC VESICLES
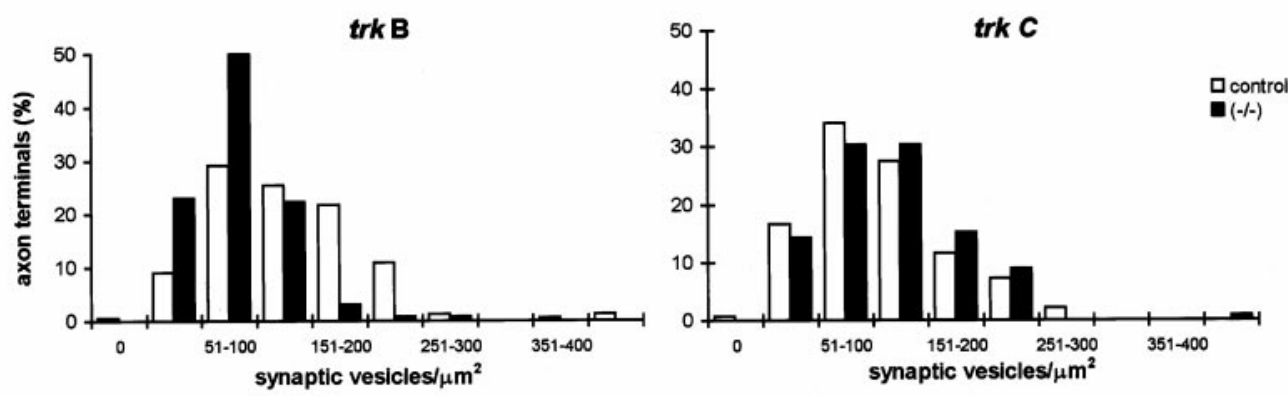

$\mathbf{F}$

SYNAPTIC VESICLES PROXIMAL TO THE ACTIVE ZONE
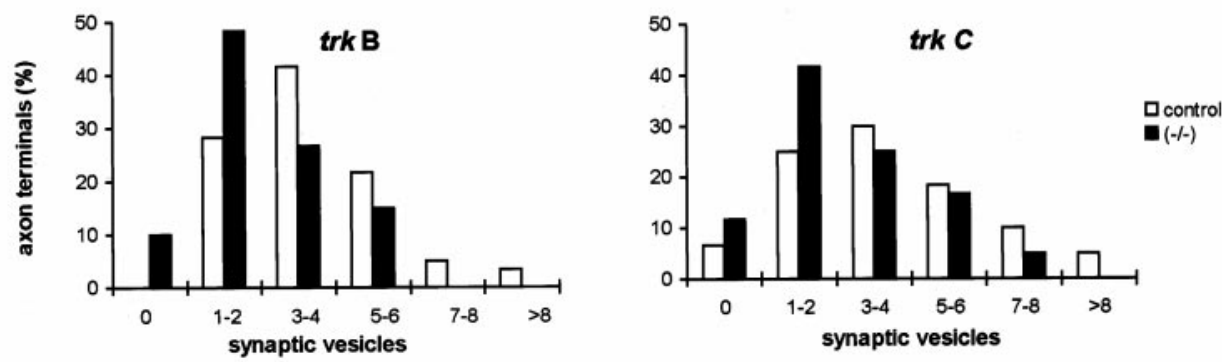

Figure 5. Fine structure of synaptic boutons in $\operatorname{trkB}(-/-)$ and $\operatorname{trk} \mathrm{C}(-/-)$ mice at P13-P14. A-C, Electron micrographs illustrating axon terminals and synaptic contacts (arrowheads) in the stratum radiatum of wild-type, trkB $(-/-)$, and trkC $(-/-)$ mice. Note decreased densities of synaptic vesicles and reduced thickness of postsynaptic specializations, especially in trkB $(-/-)$ mice. Scale bar, $0.5 \mu \mathrm{m}$. $D$, Density of synaptic contacts in different hippocampal layers in trkB $(-/-)$, trkC $(-/-)$, and littermate controls (mean $\pm \mathrm{SEM} ;{ }^{*} p<0.05 ;{ }^{* *} p<0.01$; Student's $t$ test). E-F, Histograms showing distributions of density of synaptic vesicles $(E)$ and numbers of synaptic vesicles near the active zone $(F)$ in axon terminals in the stratum lacunosum-moleculare of $\operatorname{trkB}(-/-)$ and $\operatorname{trk} \mathrm{C}(-/-)$ mice and their littermate controls. Note decreased density of synaptic vesicles in trk $\mathrm{B}(-/-)$ but not in $t r k \mathrm{C}(-/-)$ mice, and reduced numbers of synaptic vesicles clustered near the active zone in both mutant mice. AT, Axon terminal; iml, inner molecular layer; $\mathrm{mml}$, medial molecular layer; oml, outer molecular layer; $s \mathrm{~m}$, stratum lacunosum-moleculare; $s r$, stratum radiatum. 


\begin{tabular}{|c|c|c|c|c|c|c|c|c|c|c|}
\hline & \multicolumn{5}{|l|}{$\operatorname{trk} \mathrm{B}$} & \multicolumn{5}{|l|}{ trkC } \\
\hline & IML & MML & OML & SLM & SR & IML & MML & OML & SLM & SR \\
\hline \multicolumn{11}{|c|}{ Area of terminals $\left(\mu \mathrm{m}^{2}\right)$} \\
\hline Control & $0.18 \pm 0.11$ & $0.17 \pm 0.13$ & $0.17 \pm 0.12$ & $0.18 \pm 0.14$ & $0.17 \pm 0.11$ & $0.16 \pm 0.09$ & $0.15 \pm 0.11$ & $0.17 \pm 0.14$ & $0.20 \pm 0.16$ & $0.18 \pm 0.12$ \\
\hline$(-/-)$ & $0.24 \pm 0.15$ & $0.21 \pm 0.15$ & $0.21 \pm 0.14$ & $0.25 \pm 0.19$ & $0.21 \pm 0.14$ & $0.17 \pm 0.14$ & $0.14 \pm 0.10$ & $0.18 \pm 0.12$ & $0.18 \pm 0.14$ & $0.13 \pm 0.15$ \\
\hline \multicolumn{11}{|c|}{$\begin{array}{l}\text { Density of synaptic vesicles } \\
\qquad\left(n \mu \mathrm{m}^{-2}\right)\end{array}$} \\
\hline Control & $137.3 \pm 79.5$ & $121.4 \pm 85.0$ & $128.9 \pm 53.0$ & $141.2 \pm 137.4$ & $117.5 \pm 61.9$ & $106.5 \pm 60.4$ & $116.8 \pm 65.7$ & $110.8 \pm 76.3$ & $111.7 \pm 153.5$ & $97.8 \pm 52.7$ \\
\hline$(-/-)$ & $81.4 \pm 40.7$ & $84.7 \pm 48.1$ & $104.8 \pm 48.8$ & $84.9 \pm 50.3$ & $79.6 \pm 52.6$ & $116.6 \pm 66.4$ & $115.4 \pm 59.2$ & $110.4 \pm 65.7$ & $116.5 \pm 68.1$ & $112.8 \pm 83.6$ \\
\hline \multicolumn{11}{|c|}{$\begin{array}{l}\text { Vesicles in region proximal } \\
\text { to presynaptic } \\
\text { membrane }(n)\end{array}$} \\
\hline Control & $3.75 \pm 1.99$ & $3.65 \pm 1.68$ & $4.26 \pm 1.82$ & $3.53 \pm 2.31$ & $3.40 \pm 1.71$ & $3.95 \pm 2.39$ & $3.82 \pm 1.76$ & $4.16 \pm 2.09$ & $3.65 \pm 2.65$ & $3.90 \pm 2.28$ \\
\hline$(-/-)$ & $2.52 \pm 1.63$ & $2.5 \pm 1.21$ & $2.78 \pm 1.59$ & $2.5 \pm 1.59$ & $2.76 \pm 1.59$ & $3.06 \pm 1.91$ & $2.69 \pm 1.37$ & $3.00 \pm 1.85$ & $2.65 \pm 1.97$ & $2.96 \pm 1.57$ \\
\hline \multicolumn{11}{|c|}{$\begin{array}{l}\text { Width of synaptic cleft } \\
\qquad(\mathrm{nm})\end{array}$} \\
\hline Control & $17.1 \pm 2.6$ & $16.9 \pm 2.5$ & $16.6 \pm 2.2$ & $16.3 \pm 2.2$ & $16.5 \pm 2.5$ & $15.7 \pm 2.9$ & $15.7 \pm 3.0$ & $15.4 \pm 3.9$ & $15.1 \pm 2.9$ & $16.3 \pm 3.1$ \\
\hline$(-/-)$ & $16.1 \pm 1.7$ & $15.5 \pm 2.7$ & $15.6 \pm 2.2$ & $14.9 \pm 2.1$ & $15.0 \pm 2.7$ & $16.5 \pm 3.4$ & $15.6 \pm 3.9$ & $16.8 \pm 3.4$ & $15.8 \pm 3.5$ & $16.5 \pm 3.1$ \\
\hline \multicolumn{11}{|c|}{$\begin{array}{l}\text { Width of postsynaptic } \\
\text { density }(\mathrm{nm})\end{array}$} \\
\hline Control & $19.2 \pm 4.0$ & $18.6 \pm 2.9$ & $17.8 \pm 2.6$ & $19.3 \pm 2.5$ & $20.9 \pm 3.8$ & $19.5 \pm 3.0$ & $19.0 \pm 2.5$ & $18.0 \pm 2.5$ & $17.7 \pm 3.2$ & $21.0 \pm 4.2$ \\
\hline$(-/-)$ & $15.5 \pm 3.5$ & $16.5 \pm 2.9$ & $15.5 \pm 3.1$ & $14.4 \pm 3.5$ & $17.1 \pm 2.3$ & $17.7 \pm 3.2$ & $16.5 \pm 3.8$ & $16.5 \pm 3.1$ & $16.0 \pm 2.8$ & $18.6 \pm 3.3$ \\
\hline \multicolumn{11}{|c|}{$\begin{array}{l}\text { Length of synaptic contact } \\
\qquad(\mu \mathrm{m})\end{array}$} \\
\hline Control & $0.25 \pm 0.08$ & $0.24 \pm 0.06$ & $0.24 \pm 0.06$ & $0.30 \pm 0.10$ & $0.26 \pm 0.07$ & $0.22 \pm 0.07$ & $0.21 \pm 0.07$ & $0.21 \pm 0.05$ & $0.26 \pm 0.05$ & $0.24 \pm 0.08$ \\
\hline$(-/-)$ & $0.28 \pm 0.07$ & $0.26 \pm 0.06$ & $0.25 \pm 0.07$ & $0.34 \pm 0.13$ & $0.24 \pm 0.06$ & $0.22 \pm 0.10$ & $0.21 \pm 0.07$ & $0.22 \pm 0.06$ & $0.27 \pm 0.11$ & $0.22 \pm 0.06$ \\
\hline
\end{tabular}

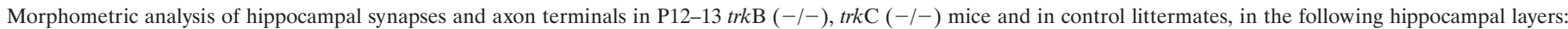

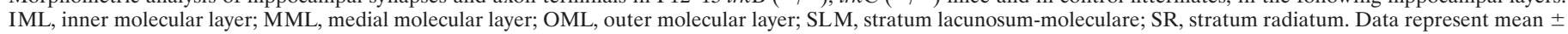
SD. Significant differences are shown in bold typeface $(p<0.05$, Student's $t$ test).

similar for all hippocampal laminae, including the layers of termination of entorhinal and commissural afferents. These data show major structural alterations of presynaptic axon terminals and synapses in mice lacking TrkB receptors, and to a lesser extent, in those lacking TrkC, which supports a role of neurotrophic factors in the functional maturation of CNS synapses.

\section{Expression of synaptic-associated proteins in trkB $(-I-)$ and trkC (-I-) mice}

Some of the synaptic abnormalities reported above are similar to those described in null-mutant mice for genes encoding synapticassociated proteins (Rosahl et al., 1993; Li et al., 1995; Takei et al., 1995). To examine whether the distribution and expression of these proteins were altered in trkB $(-/-)$ and $\operatorname{trk} \mathrm{C}(-/-)$ mice, we performed an immunocytochemical analysis. Consistent with the electron microscopic observations, confocal microscopy analysis of immunoreacted sections showed that the synaptic vesicle proteins synapsin I and synaptophysin were markedly reduced in trkB (-/-) mice among all hippocampal layers (38-71\%), especially in the stratum radiatum (Figs. 6, 7). These proteins are considered to be integral proteins of synaptic vesicles and thus markers of synaptic vesicle populations. A dramatic decrease was also observed in trkB (-/-) animals in the immunolabeling for the synaptic vesicle protein synaptotagmin I (31-56\% reduction) (Figs. 6, 7), a v-SNARE essential for neurotransmitter release (Geppert et al., 1994b). In contrast, immunostaining for synaptobrevin 2, another $\mathrm{v}$-SNARE protein, was not decreased in trkB $(-/-)$ animals but showed a slight increase in some layers $(16 \%)$.
We next examined the distribution of the synaptic membrane proteins SNAP-25 and syntaxin 1, which are essential t-SNAREs for calcium-dependent exocytosis and neurotransmitter release (Blasi et al., 1993; Südhof, 1995; Hay and Scheller, 1997). Although syntaxin 1-immunostaining was dramatically reduced (60-68\% reduction), the immunolabeling for SNAP-25 was decreased notably in the hippocampus proper (40-56\% reduction) but not in the dentate gyrus (20\% reduction) (Figs. 6, 7). Similarly, the small GTP-binding protein Rab3a, which is believed to regulate synaptic vesicle fusion (Geppert et al., 1994a, 1997), was also significantly reduced in these mutant mice (53-63\%) (Fig. 7). We conclude that most synaptic-associated proteins, except synaptobrevin 2 , are differentially downregulated in trkB $(-/-)$ mice with distinguishing patterns of laminar changes. In addition, the profiles of reductions were different for each protein and in general were more dramatic in the hippocampus proper than in the dentate gyrus.

In trkC $(-/-)$ mice, in contrast, only the immunocytochemical signal for synapsin 1 was dramatically reduced (52-64\% reduction) (Fig. 7), whereas the v-SNAREs synaptotagmin I and synaptobrevin 2 and the t-SNARE syntaxin 1 showed moderate decreases $(19-45 \%)$. None of the remaining synaptic proteins studied, including synaptophysin, SNAP-25, and Rab3a, showed major changes in these mutants compared with wild-type littermates (Figs. 6, 7).

To further support the view that synaptic-associated proteins were downregulated in these mutants, we performed biochemical 

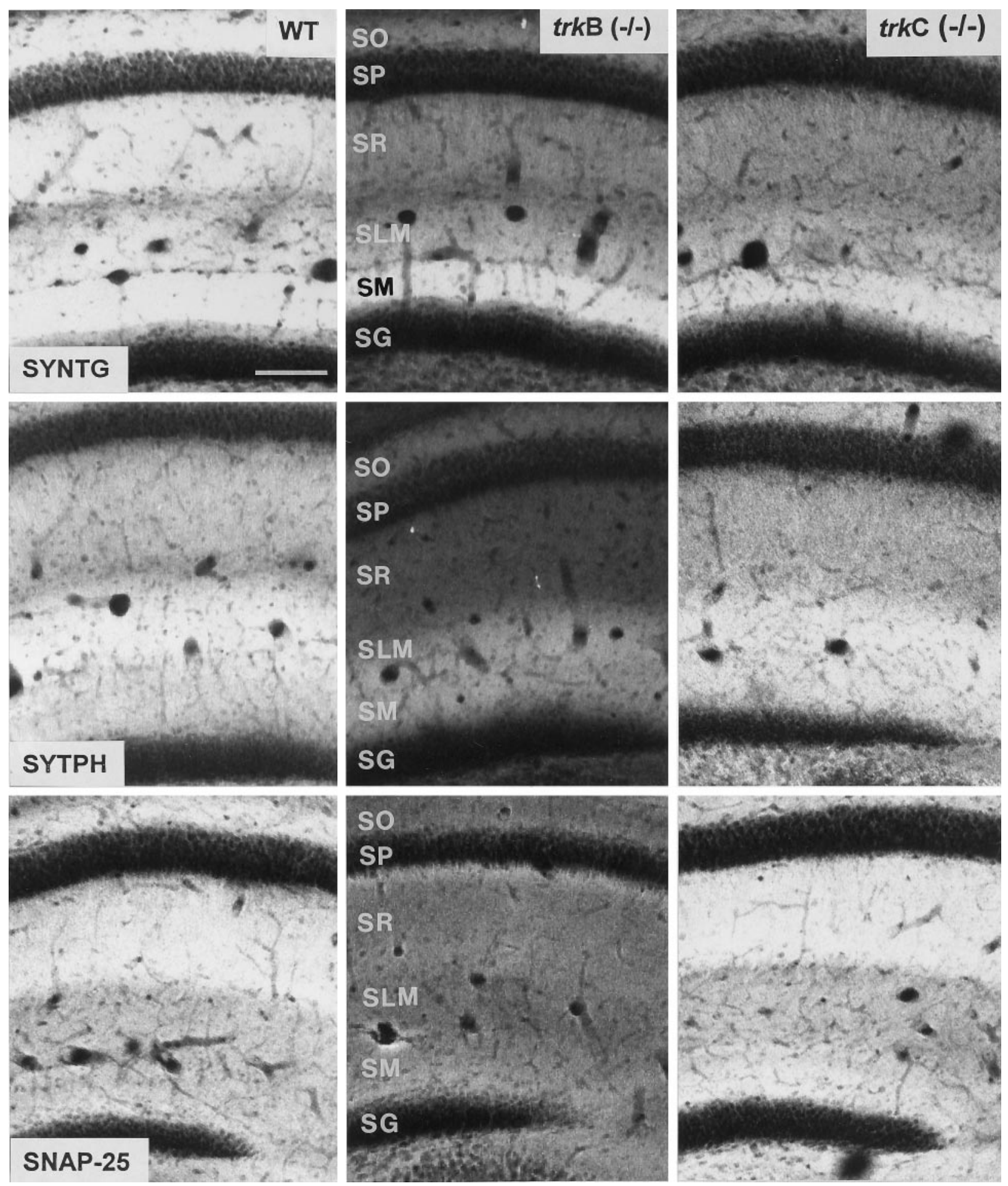

Figure 6. Immunolabeling for different synaptic-associated proteins in hippocampal sections of wild-type (left column), trkB (-/-) (middle column), and trkC (-/-) (right column) mice (P14) (SYNTG, synaptotagmin I; SYTPH, synaptophysin; and SNAP-25). Laser confocal microscopy photomicrographs are reconstructions of two $2-\mu \mathrm{m}$-thick confocal sections. To allow comparison of mutant and control littermates, sections were immunolabeled in bulk and photographed in identical conditions. Abbreviations as in Figure 2. Scale bar, $150 \mu \mathrm{m}$.

studies. Western blot analyses confirmed a marked reduction (27-46\%) of synaptic-associated protein levels in the forebrain of trkB (-/-) mutant mice compared with control littermates (Fig. 8). $\operatorname{trkC}(-/-)$ mice, in contrast, showed moderate reduction of protein levels. Taken together, these findings show that the lack of
TrkB and, to a lesser extent, TrkC signaling leads to downregulation of both synaptic vesicle and synaptic membrane proteins responsible for synaptic vesicle docking and fusion, and neurotransmitter release at synaptic sites (Südhof, 1995; Hay and Scheller, 1997). 
SYN1

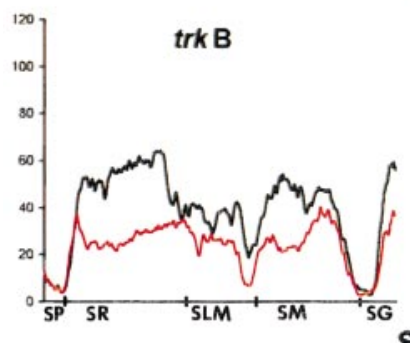

SYNTG

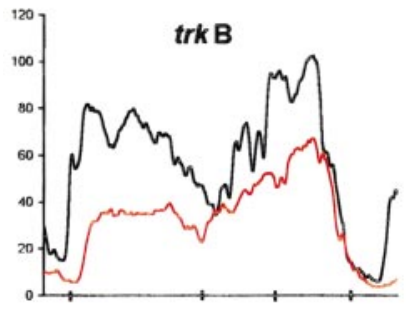

SNAP-25

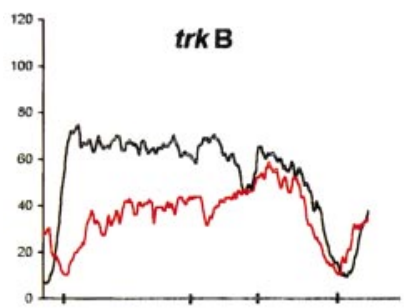

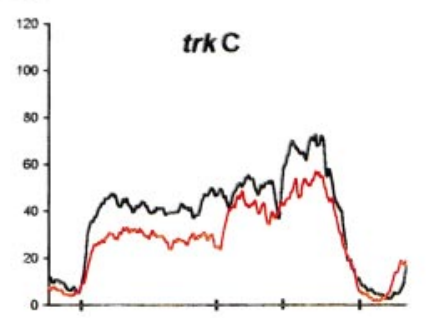
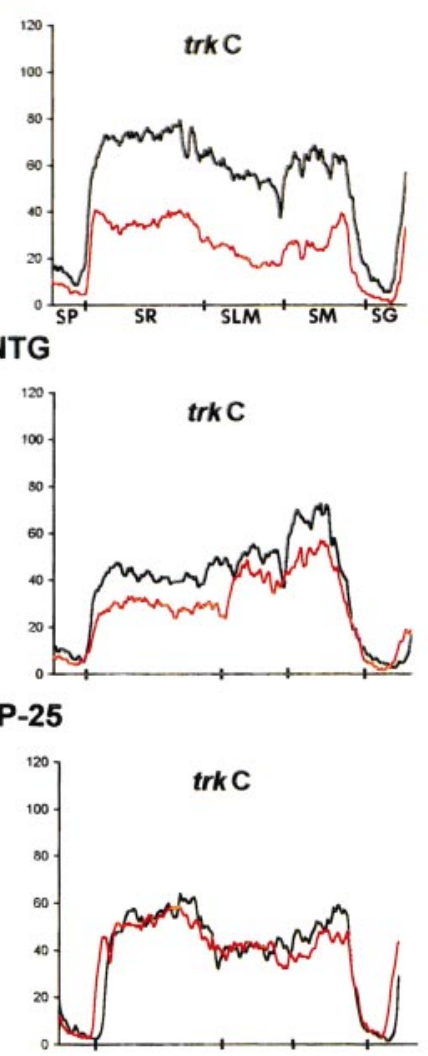

SYTPH
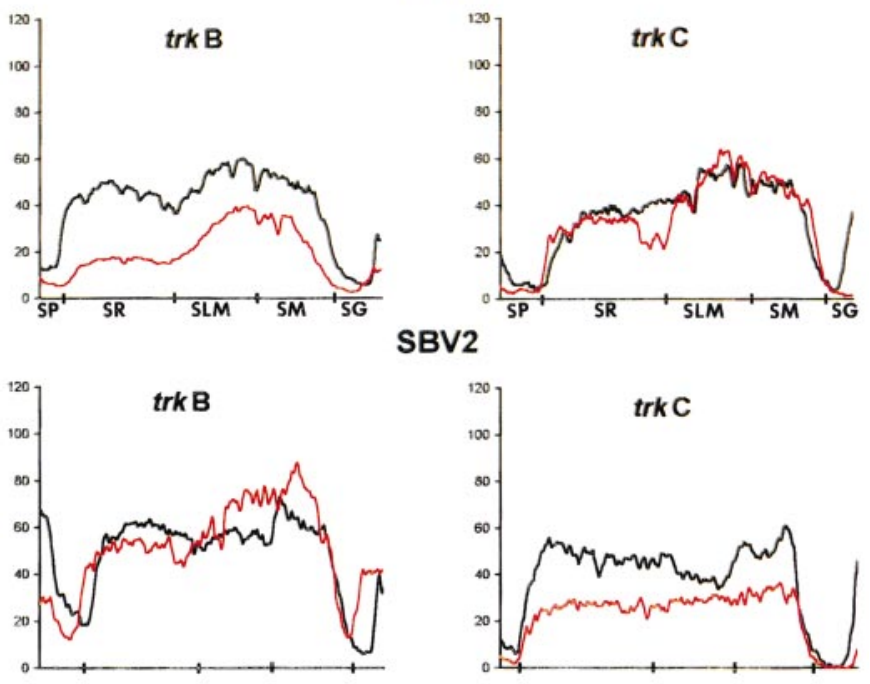

SYTX1
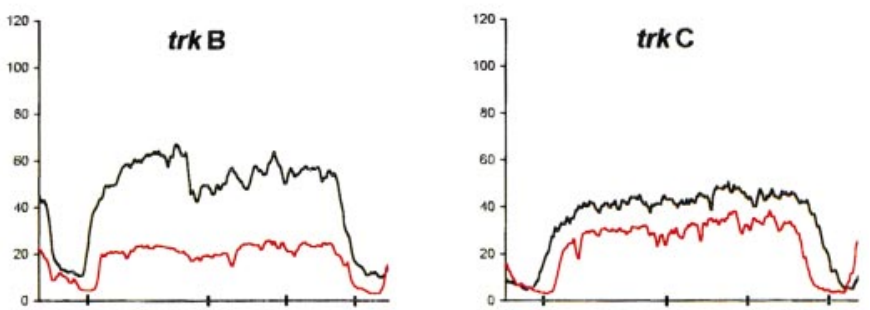

Rab3a
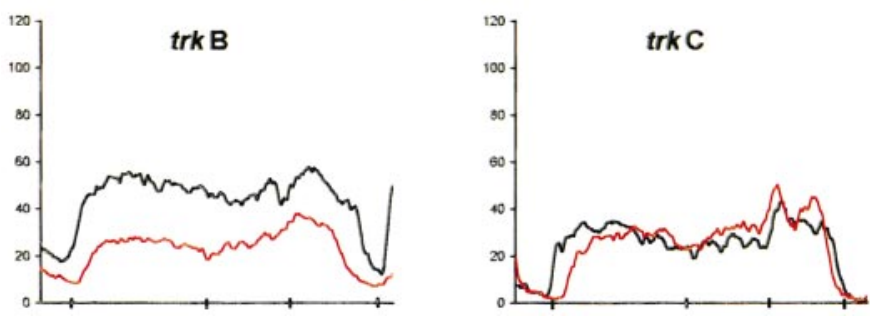

Figure 7. Quantitative determination of immunofluorescence signals in trkB (-/-) and trkC (-/-) mice and in control littermates. Diagrams show continuous linear profiles of fluorescence intensity in vertical stripes of hippocampal sections from the stratum pyramidale to the stratum granulare, for different synaptic-associated protein immunolabeling ( $S Y N 1$, synapsin 1; SYTPH, synaptophysin; SYNTG, synaptotagmin; SBV2, synaptobrevin 2; SYTX1, syntaxin 1; SNAP-25; Rab3a). The correspondence with hippocampal layers is indicated on the $x$-axis. The intensities of fluorescence are represented in gray levels ( $y$-axis). The profiles of null-mutant (red lines) and their control littermates (black lines) are displayed in the same diagram to allow comparison.

\section{DISCUSSION}

\section{TrkB and TrkC receptors are not required for the development of layer-specific connections in the hippocampus}

Studies in the PNS have implicated target-derived neurotrophins in the guidance and growth of developing axons and in the regulation of the density of innervation (Edwards et al., 1989; Diamond et al., 1992; Miller et al., 1994; Causing et al., 1997; Fritzsch et al., 1997; Paves and Saarma, 1997; Song et al., 1997). In the CNS, several studies in vitro and in vivo have shown that exogenous neurotrophins may regulate axonal and collateral branching in several brain regions (Cabelli et al., 1995; CohenCory and Fraser, 1995; Galuske et al., 1996; Bolz et al., 1997; Inoue and Sanes, 1997). A recent study, using inf usion of blocking TrkB-IgG fusion proteins, has shown that endogenous BDNF or
NT4 is necessary for the formation of ocular dominance columns in the visual cortex of kittens (Cabelli et al., 1997).

The present study has analyzed, for the first time, the development of neuronal connections in the CNS in vivo in the absence of endogenous TrkB and TrkC signaling and in the absence of both receptors. We show that in trk $\mathrm{B}(-/-)$ and $\operatorname{trk} \mathrm{C}(-/-)$ mice, the main afferents to the hippocampus, the commissural and entorhinal axons, grow into the target hippocampal region with a timing and pattern of termination similar to that in wild-type animals (Supèr and Soriano, 1994; Del Río et al., 1997; Supèr et al., 1998). Most notably, the highly precise laminated connections of the hippocampal region are preserved in these mutant mice. Because both TrkB and TrkC receptors are expressed in the neurons of origin of entorhinal and commissural afferents during development, we conclude that these receptors and their cognate 


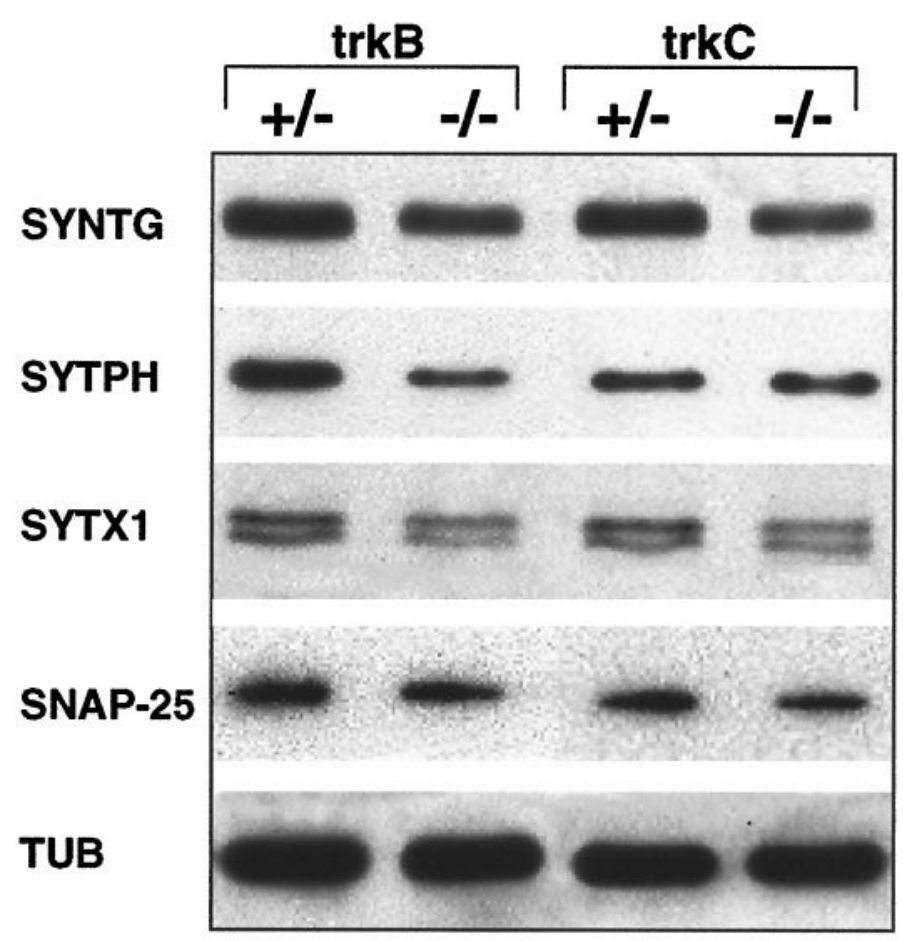

Figure 8. Immunoblot analysis of the synaptic proteins synaptotagmin I (SYNTG), synaptophysin (SYTPH), syntaxin 1 (SYTX1), SNAP-25, and of $\alpha$-tubulin $(T U B)$ in trkB $(-/-)$ and trkC $(-/-)$ mice and control littermates. Densitometric analysis $(n=2$ animals per group, considering $\alpha$-tubulin levels as reference) revealed decreases of $27 \%$ (SYNTG), $44 \%$ (SYTPH), 39\% (SYTX1), and 46\% (SNAP-25) in trkB (-/-) mice compared with control littermates. trkC $(-/-)$ mice showed moderate reductions in SNAP-25 (24\%) and synaptotagmin (22\%), and slight reductions $(7-5 \%)$ in synaptophysin and syntaxin 1 .

ligands BDNF/NT4 and NT3 are not essential for the ingrowth or layer-specific targeting of hippocampal afferents. This conclusion is supported by our observations in double-mutant mice showing that the lack of both TrkB and TrkC signaling does not alter the ingrowth or laminated pattern of hippocampal connections.

\section{Neurotrophins, formation of topographic maps, and neuronal activity}

As in other brain regions, the development of topographic projections from the medial and lateral entorhinal cortex to the hippocampus passes through a period of exuberancy followed by refinement and final shaping of adult connections. Thus, axons from both the lateral and medial entorhinal cortex initially innervate the entire stratum lacunosum-moleculare from CA3 to the subiculum; the characteristic patches of medial and lateral entorhinal innervation attain an adult-like appearance by P10-P12 (Supèr and Soriano, 1994; Del Río et al., 1997; Supèr et al., 1998). The present findings suggest that neurotrophins do not play a role in the shaping of topographic connections in the hippocampus because $t r k \mathrm{~B}(-/-)$ and $t r k \mathrm{C}(-/-)$ mice have normal patterns of projections from the lateral and medial entorhinal cortex. Because double-mutant mice die soon after birth, we cannot determine whether the lack of both TrkB and TrkC receptors influences the formation of lateral and medial projections, because the topography of these projections is not well preserved in vitro.

In the visual system, application of exogenous BDNF and NT4 or infusion of TrkB-IgG fusion proteins in the postnatal period prevents the formation of ocular dominance columns (Cabelli et al., 1995, 1997; Galuske et al., 1996; Hata et al., 1996). These observations suggest that neuronal activity by thalamocortical axons may control the expression of neurotrophins in target neurons in layer IV, which in turn may act as retrograde signals for axonal growth and synaptic stabilization through a Hebbian mechanism (Katz and Shatz, 1996; Cabelli et al., 1997). In addition, neurotrophins present in limited amounts may also be responsible for the retraction of thalamocortical collaterals that accompanies the formation of ocular dominance columns.

Several differences may be considered between the development of hippocampal connections and that of ocular dominance columns. For instance, it is not known whether the refinement of hippocampal connections depends on neuronal activity. Another difference is that the medial and lateral entorhinal projections terminate onto distinct classes of pyramidal neurons (CA1, CA2, CA3, and subicular cells), which have different developmental histories, afferent and efferent connections, electrophysiological properties, and patterns of gene expression (Stanfield and Cowan, 1988; Amaral and Witter, 1995; Freund and Buzsaki, 1996). This allows a scenario in which different pyramidal neurons may express distinct molecules influencing axonal growth, which is unlikely to occur in early columns of neurons in layer IV of the visual cortex. Thus, all the available evidence suggests that the building of neural connections in the hippocampus depends on the expression of selective molecules (such as ephrins and semaphorins) in subsets of pyramidal neurons.

\section{Neurotrophins regulate axonal branching of hippocampal connections}

Exogenous BDNF and NT3 have been shown to enhance axonal growth and branching in a number of brain regions (Cabelli et al., 1995, 1997; Cohen-Cory and Fraser, 1995; Bolz et al., 1997; Inoue and Sanes, 1997). Neurotrophins also regulate the growth and maturation of dendritic trees in the developing cerebral cortex in an activity-dependent manner (McAllister et al., 1995, 1996, 1997). The present data provide evidence that axonal branching of both commissural and entorhinal fibers is decreased in trkB $(-/-)$ and trkC $(-/-)$ animals, which supports a role for the endogenous neurotrophins BDNF/NT4 and NT3 in the elaboration and maturation of hippocampal afferent fibers.

The above studies have often reported specific, and even opposing, effects of BDNF/NT4 and NT3 on axonal growth. The present observations show consistent reductions of axonal arbors in both trkC $(-/-)(26-49 \%$ reduction) and trkB (-/-) $(20-36 \%$ reduction) animals, which suggests that ligands of both TrkB and TrkC receptors cooperate in the elaboration and branching of hippocampal afferents. This notion is consistent with the coexpression of $t r k \mathrm{~B}$ and $t r k \mathrm{C}$ transcripts in the hippocampal afferent neurons during development.

\section{Neurotrophins and synaptogenesis in the CNS}

We show here for the first time that the lack of endogenous TrkB and TrkC receptors alters synaptogenesis in the CNS by reducing the density of synaptic contacts, which supports a role for neurotrophic factors in the regulation of the number of synapses during development (Snider and Litchman, 1996). The reduction in synaptic density (number of synapses per unit area) was more dramatic in $t r k \mathrm{~B}(-/-)$ mice $(17-39 \%)$ than in $t r k \mathrm{C}(-/-)$ animals (11-17\%). Because the size and area of the afferent termination layers in the hippocampus of these homozygous mutant mice are smaller than those of control littermates [21\% and $18 \%$ 
reduction of layers in trkB $(-/-)$ and trkC $(-/-)$ mice, respectively, as estimated in Nissl-stained sections], the reduction in the total number of synaptic inputs is higher. This reduction in the total number of hippocampal synapses can be estimated as 34$52 \%$ and $25-30 \%$ for $\operatorname{trkB}(-/-)$ and trkC $(-/-)$ mice, respectively.

Postnatal trkB (-/-) mice show increased neuronal cell death in some of the populations of hippocampal afferent neurons, such as the CA3 pyramidal cells (Alcántara et al., 1997). The decreased synaptic innervation in part may be the result of a reduction in the number of neurons. Although neuronal cell death may account for some of the reduction in synaptic innervation, our findings show that homozygous mutant mice display decreased branching and elaboration of single axonal arbors and reduced densities of axonal varicosities along axon collaterals (Fig. 3). These results indicate that the reduced synaptic innervation is also attributable to an effect of the mutations on developing afferent axons.

\section{Neurotrophins and the functional maturation of synapses: regulation of v-SNAREs and t-SNAREs}

This study reports for the first time that the axon terminals of trkB and trkC kinase-deficient mice display dramatic fine structural abnormalities, such as decreased density of synaptic vesicles and less prominent clustering of synaptic vesicles near the active zone. These findings suggest that the absence of TrkB and TrkC signaling interferes with the functional maturation of the presynaptic machinery, in particular by altering the number of synaptic vesicles or their exocytotic/endocytotic cycle or both. In agreement with this notion, we report here a dramatic and specific downregulation of presynaptic proteins, including t-SNARE and v-SNARE proteins, responsible for synaptic vesicle fusion (Blasi et al., 1993; Südhof, 1995; Geppert et al., 1997; Hay and Scheller, 1997; Martin, 1997). Such a downregulation is unlikely to be solely the consequence of a decreased synaptic density because the reductions of protein levels are very heterogeneous (Figs. 6, 7). For instance, decreased immunocytochemical signals in trkB $(-/-)$ mice range from the virtual disappearance of syntaxin 1-immunostaining to no detectable changes in synaptobrevin 2 . This is more evident in trkC $(-/-)$ animals, which show a selective reduction in the immunological signals of only three synaptic proteins. Taken together these observations support a role of neurotrophins in the developmental maturation of synaptic structure and function by regulating the levels of some, but not all, presynaptic proteins (Wang et al., 1995; Takei et al., 1997).

Because similar structural and biochemical changes in mice lacking synaptic-associated proteins are linked to altered synaptic function and neurotransmitter release (Rosahl et al., 1993; Li et al., 1995; Takei et al., 1995; Castillo et al., 1997), it is tempting to speculate that $\mathrm{Ca}^{2+}$-dependent synaptic vesicle dynamics and neural transmission may be altered in trkB and trkC-deficient mice. Neurotrophins and presynaptic Trk receptors have been shown to potentiate neurotransmitter release (Lohof et al., 1993; Kang and Schuman, 1995; Korte et al., 1995; Wang and Poo, 1997), and BDNF is necessary for induction of LTP (Korte et al., 1995). These actions are thought to be mediated by presynaptic Trk activation and phosphorylation of some synaptic proteins, such as synapsin I (Jovanovic et al., 1996). We propose that TrkB and TrkC receptors not only modify the presynaptic machinery locally, but they also regulate synaptic protein levels during development. This may suggest that transcriptional regulation of $\mathrm{v}$-SNAREs and t-SNAREs is one of the mechanisms by which neurotrophins contribute to the activity-dependent plasticity of the developing and adult CNS.

\section{REFERENCES}

Alcántara S, Frisén J, Del Río JA, Soriano E, Barbacid M, Silos-Santiago I (1997) TrkB signaling is required for postnatal survival of CNS neurons and protects hippocampal and motor neurons from axotomyinduced cell death. J Neurosci 17:3623-3633.

Altar CA, Cai N, Bliven T, Juhasz M, Conner JM, Acheson AL, Lindsay RM, Wiegand SJ (1997) Anterograde transport of brain-derived neurotrophic factor and its role in the brain. Nature 386:856-860.

Amaral DG, Witter MP (1995) Hippocampal formation. In: The rat nervous system (Paxinos G, ed), pp 433-493. San Diego: Academic.

Barnstable CJ, Hofstein R, Akagawa K (1985) A marker for amacrine cell development in rat retina. Dev Brain Res 20:286-290.

Blasi J, Chapman ER, Link E, Binz T, Yamasaki S, DeCamilli P, Südhof TC, Niemann H, Jahn R (1993) Botulinum neurotoxin A selectively cleaves the synaptic protein SNAP-25. Nature 365:160-163.

Bolz J, Castellani V, Batardière A (1997) Neurotrophic factors play a role in the elaboration of local cortical circuits. Soc Neurosci Abstr 23:1433.

Brose N, Petrenko AG, Südhof TC, Jahn R (1992) Synaptotagmin: a calcium sensor on the synaptic vesicle surface. Science 256:1021-1025.

Cabelli RJ, Hohn A, Shatz T (1995) Inhibition of ocular dominance column formation by infusion of NT-4/5 or BDNF. Science 267:1662-1666.

Cabelli RJ, Shelton DL, Segal RA, Shatz CJ (1997) Blockade of endogenous ligands of TrkB inhibits formation of ocular dominance columns. Neuron 19:63-76.

Castillo PE, Janz R, Südohf TC, Tzounopoulos T, Malenka RC, Nicoll RA (1997) Rab3a is essential for mossy fibre long-term potentiation in the hippocampus. Nature 388:590-593.

Causing CG, Gloster A, Aloyz R, Bamji SX, Chang E, Fawcett J, Kuchel G, Miller FD (1997) Synaptic innervation density is regulated by neuron-derived BDNF. Neuron 18:257-267.

Cohen-Cory S, Fraser SE (1995) Effects of brain-derived neurotrophic factor on optic axon branching and remodelling in vitro. Nature 378:192-196.

Davies AM (1996) Paracrine and autocrine actions of neurotrophic factors. Neurochem Res 21:749-753.

Del Río JA, Heimrich B, Borrell V, Förster E, Drakew A, Alcántara S, Nakajima K, Miyata T, Ogawa M, Mikoshiba K, Derer P, Frotscher M, Soriano E (1997) A role of Cajal-Retzius cells and reelin in the development of hippocampal connections. Nature 385:70-74.

Diamond J, Holmes M, Coughlin M (1992) Endogenous NGF and nerve impulses regulate the collateral sprouting of sensory axons in the skin of the adult rat. J Neurosci 12:1454-1466.

Edelmann L, Hanson PI, Chapman ER, Jahn R (1995) Synaptobrevin binding to Synaptophysin: a potential mechanism for controlling the exocytotic fusion machine. EMBO J 14:224-231.

Edwards RM, Rutter WJ, Hanahan D (1989) Directed expression of NGF to pancreatic $\beta$ cells in transgenic mice leads to selective hyperinnervation of the islets. Cell 58:161-170.

Ernfors P, Wetmore C, Olson L, Persson H (1990) Identification of cells in rat brain and peripheral tissues expressing mRNA for members of the nerve growth factor family. Neuron 5:511-526.

Ernfors P, Bengzon J, Kokaia Z, Persson H, Lindvall A (1991) Increased levels of messenger RNAs for neurotrophic factors in the brain during kindling epileptogenesis. Neuron 7:165-176.

Fariñas I, Reichardt LF (1996) Neurotrophic factors and their receptors: implications of genetic studies. Semin Neurosci 8:133-143.

Figurov A, Pozzo-Miller LD, Olaffson P, Wang T, Lu B (1996) Regulation of synaptic responses to high-frequency stimulation and LTP by neurotrophins in the hippocampus. Nature 381:706-709.

Freund TF, Buzsaki G (1996) Interneurons of the hippocampus. Hippocampus 6:345-470.

Fritzsch B, Silos-Santiago I, Bianchi LM, Fariñas I (1997) The role of neurotrophic factors in regulating the development of inner ear innervation. Trends Neurosci 20:159-164.

Frotscher M, Heimrich B (1993) Formation of layer-specific fiber projections to the hippocampus in vitro. Proc Natl Acad Sci USA 90:10400-10403. 
Gall CM, Isackson PJ (1989) Limbic seizures increase neuronal production of messenger RNA for nerve growth factor. Science 245:758-761.

Gall CM, Murray K, Isackson PJ (1991) Kainic acid-induced seizures stimulate increased expression of nerve growth factor mRNA in rat hippocampus. Mol Brain Res 9:113-123.

Galuske RAW, Kim D-S, Castren E, Thoenen H, Singer W (1996) Brain-derived neurotrophic factor reverses experience-dependent synaptic modifications in kitten visual cortex. Eur J Neurosci 8:1554-1559.

Geppert M, Bolshakov VY, Siegelbaum SA, Takel K, De Camilli P,Hammer RE, Südhof TC (1994a) The role of Rab3A in neurotransmitter release. Nature 369:493-497.

Geppert M, Goda Y, Hammer RE, Li C, Roshal TW, Stevens CF, Südhof TC (1994b) Synaptotagmin I: a major $\mathrm{Ca}^{2+}$ sensor for transmitter release at a central synapse. Cell 79:717-727.

Geppert M, Goda Y, Stevens CF, Südhof TC (1997) The small GTPbinding protein Rab3a regulates a late step in synaptic vesicle fusion. Nature 387:810-814.

Hata Y, Katsuyama N, Fukuda M, Ohshima M, Tsumoto T, Hatanaka H (1996) Brain-derived neurotrophic factor disrupts effects of monocular deprivation in kitten visual cortex. Soc Neurosci Abstr 22:1728.

Hay JC, Scheller RH (1997) SNAREs and NSF in targeted membrane fusion. Curr Opin Cell Biol 9:505-512.

Hofer M, Pagliusi SR, Hohn A, Leibrok J, Barde Y-A (1990) Regional distribution of brain-derived neurotrophic factor RNA in the adult mouse brain. EMBO J 9:2459-2464.

Inoue A, Sanes JR (1997) Lamina-specific connectivity in the brain: regulation by $\mathrm{N}$-cadherin, neurotrophins, and glycoconjugates. Science 276:1428-1431.

Isackson PJ (1995) Trophic factor response to neuronal stimuli or injury. Curr Opin Neurobiol 5:350-357.

Isackson PJ, Huntsman MM, Murray KD, Gall CM (1991) BDNF mRNA expression is increased in adult rat forebrain after limbic seizures: temporal patterns of induction distinct from NGF. Neuron 6:937-948.

Jones KR, Fariñas I, Backus C, Reichardt LF (1994) Targeted disruption of the BDNF gene perturbs brain and sensory neuron development but not motor neuron development. Cell 76:989-999.

Jovanovic JN, Benfenati F, Siow YL, Sihra TS, Sanghera JS, Pelech SL, Greengard P, Czernik J (1996) Neurotrophins stimulate phosphorylation of synapsin I by MAP kinase and regulate synapsin I-actin interactions. Proc Natl Acad Sci USA 93:3679-3683.

Kang H, Schuman EM (1995) Long-lasting neurotrophin induced enhancement of synaptic transmission in the adult hippocampus. Science 267:1658-1662.

Katz LC, Shatz CJ (1996) Synaptic activity and the construction of cortical circuits. Science 274:1133-1138.

Klein R, Nanduri V, Jing S, Lamballe F, Tapley P, Bryant S, CordonCardo C, Jones KR, Reichardt LF, Barbacid M (1991) The trkB tyrosine protein kinase is a receptor for brain-derived neurotrophic factor and neurotrophin-3. Cell 66:395-403.

Klein R, Lamballe F, Bryant S, Barbacid M (1992) The trkB tyrosine protein kinase is a receptor for neurotrophin-4. Neuron 8:947-956.

Klein R, Smeyne RJ, Wurst W, Long LK, Auerbach BA, Joyner AL, Barbacid M (1993) Targeted disruption of the trkB neurotrophin receptor gene results in nervous system lesions and neonatal death. Cell 75:113-122.

Klein R, Silos-Santiago I, Smeyne RJ, Lira S, Brambilla S, Bryant S, Zhang L, Snider WD, Barbacid M (1994) Disruption of the neurotrophin receptor gene trkC eliminates muscle afferents and results in abnormal movements. Nature 368:249-251.

Korte M, Carroll P, Wolf E, Brem G, Thoenen H, Bonhoeffer T (1995) Hippocampal long-term potentiation is impaired in mice lacking BDNF. Proc Natl Acad Sci USA 92:8856-8880.

Lamballe F, Klein R, Barbacid M (1991) trkC, a new member of the trk family of tyrosine protein kinases, is a receptor for neurotrophin-3. Cell 66:967-979.

Lecea L, Del Río JA, Soriano E (1995) Developmental expression of parvalbumin mRNA in the cerebral cortex and hippocampus of the rat. Mol Brain Res 32:1-13.

Lecea L, Del Río JA, Alcántara S, Criado JR, Morales M, Henriksen S, Soriano E, Sutcliffe G (1997) Cortistatin is expressed in a distinct subset of cortical interneurons. J Neurosci 17:5868-5880.

Li D, Field PM, Starega U, Li Y, Raisman G (1993) Entorhinal axon project to dentate gyrus in organotypic slice co-culture. Neuroscience 52:799-813.

Li L, Chin LS, Shupliakov O, Brodin L, Shira TS, Hvalby O, Jensen V, Zheng D, McNamara JO, Greengard P, Andersen P (1995) Impairment of synaptic vesicle clustering and of synaptic transmission, and increased seizure propensity, in synapsin I-deficient mice. Proc Natl Acad Sci USA 92:9235-9239.

Lindvall O, Ernfors P, Bengzon J, Kokaia Z, Smith ML, Siesjö BK, Persson H (1992) Differential regulation of mRNAs for nerve growth factor, brain-derived neurotrophic factor, and neurotrophin-3 in the adult rat brain following cerebral ischemia and hypoglycemic coma. Proc Natl Acad Sci USA 89:648-652.

Liu ZZ, Zhu LQ, Eide FF (1997) Critical role of TrkB and brainderived neurotrophic factor in the differentiation and survival of retinal pigment epithelium. J Neurosci 17:8749-8755.

Lohof AM, Ip NY, Poo M (1993) Potentiation of developing neuromuscular synapses by the neurotrophins NT-3 and BDNF. Nature 363:350-353.

Martin TFJ (1997) Stages of regulated exocytosis. Trends Cell Biol 7:271-276.

Matteoli M, Takei K, Cameron R, Hurlbut P, Johnston PA, Sudhof TC, Jahn R, De Camilli P (1991) Association of Rab3a with synaptic vesicles at the late stages of the secretory pathway. J Cell Biol 115:625-633.

McAllister AK, Lo DC, Katz LC (1995) Neurotrophins regulate dendritic growth in developing visual cortex. Neuron 15:791-803.

McAllister AK, Katz LC, Lo DC (1996) Neurotrophin regulation of cortical dendritic growth requires activity. Neuron 17:1057-1064.

McAllister AK, Katz LC, Lo DC (1997) Opposing roles for endogenous BDNF and NT-3 in regulating cortical dendritic growth. Neuron 18:767-778.

Miller FD, Speelma A, Mathew TC, Fabian J, Chang E, Pozniak C, Toma JG (1994) Nerve growth factor derived from terminals selectively increases the ratio of $\mathrm{p} 75$ to trkA NGF receptors on mature sympathetic neurons. Dev Biol 161:206-217.

Minichiello L, Klein R (1996) TrkB and TrkC neurotrophin receptors cooperate in promoting survival of hippocampal and cerebellar granule neurons. Genes Dev 19:2849-2858.

Paves H, Saarma M (1997) Neurotrophins as in vitro growth cone guidance molecules for embryonic sensory neurons. Cell Tissue Res 290:285-298.

Prakash N, Cohen-Cory S, Frostig RD (1996) Rapid and opposite effects of BDNF and NGF on the functional organization of the adult cortex "in vivo". Nature 381:702-706.

Rocamora N, Pascual M, Ascady L, de Lecea L, Freund T (1996) Expression of NGF and NT3 mRNAs in hippocampal interneurons innervated by the GABAergic septohippocampal pathway. Neuron 16:3991-4004.

Rosahl TW, Geppert M, Spillane D, Herz J, Hammer RE, Malenka RC, Südhof TC (1993) Short-time synaptic plasticity is altered in mice lacking synapsin I. Cell 75:661-670.

Rosahl TW, Spillane D, Missler M, Herz J, Selig DK, Wolff JR, Hammer RE, Malenka RC, Südhof TC (1995) Essential function of synapsins I and II in synaptic vesicle regulation. Nature 375:488-493.

Silos-Santiago I, Fagan AM, Garber M, Fritzsch B, Barbacid M (1997) Severe sensory deficits but normal CNS development in newborn mice lacking TrkB and TrkC tyrosine protein kinase receptors. Eur J Neurosci 9:2045-2056.

Snider WD (1994) Functions of the neurotrophins during nervous system development: what are knockouts teaching us. Cell 77:627-638.

Snider WD, Litchman J (1996) Are neurotrophins synaptotrophins? Mol Cell Neurosci 7:433-442.

Snider WD, Silos-Santiago I (1996) Dorsal root ganglion neurons require functional neurotrophin receptors for survival during development. Philos Trans R Soc Lond B Biol Sci 351:395-403.

Song H-J, Ming G-L, Poo M-M (1997) cAMP-induced switching in turning direction of nerve growth cones. Nature 388:275-279.

Soppet D, Escandon E, Maragos J, Middlemas DS, Reid SW, Blair J, Burton LE, Stanton BR, Kaplan DR, Hunter T, Nickolics K, Parada LF (1991) The neurotrophic factors brain-derived neurotrophic factor and neurotrophin-3 are ligands for the trkB tyrosine kinase receptor. Cell 65:895-903.

Stanfield BB, Cowan WM (1988) The development of the hippocam- 
pal region. In: Development and maturation of cerebral cortex. Cerebral Cortex. Vol VII (Peters A, Jones EG), pp 91-122. New York: Plenum.

Stoppini L, Buchs PA, Muller D (1991) A simple method for organotypic cultures of nervous tissue. J Neurosci Methods 37:173-182.

Südhof TC (1995) The synaptic vesicle cycle: a cascade of proteinprotein interactions. Nature 375:645-653.

Supèr H, Soriano E (1994). The organization of the embryonic and early postnatal murine hippocampus. II. Development of entorhinal, commissural, and septal connections studied with the lipophilic tracer DiI. J Comp Neurol 344:101-120.

Supèr H, Martínez A, Del Río JA, Soriano E (1998) Involvement of distinct pioneer neurons in the formation of layer-specific connections in the hippocampus. J Neurosci 18:4616-4626.

Takei Y, Harada A, Takeda S, Kobayashi K, Terada S, Noda T, Takahashi T, Hirokawa N (1995) Synapsin I deficiency results in the structural change in the presynaptic terminals in the murine nervous system. J Cell Biol 131:1789-1800.
Takei N, Sasaoka K, Inoue K, Takahashi M, Endo Y, Hatanaka H (1997) Brain-derived neurotrophic factor increases the stimulation-evoked release of glutamate and the levels of exocytosis-associated proteins in cultured cortical neurons from embryonic rats. J Neurochem 68:370-375.

Thoenen H (1995) Neurotrophins and neuronal plasticity. Science 270:593-598.

Tonra JR, Cutis R, Wong V, Cliffer KD, Park JS, Timmes A, Nguyen T, Lindsay RM, Acheson A, DiStefano PS (1998) Axotomy upregulates the anterograde transport and expression of BDNF by sensory neurons. J Neurosci 18:4374-4383.

Von Bartheld CS, Byers MR, Williams R, Bothwell M (1996) Anterograde transport of neurotrophins and axodendritic transfer in the developing visual system. Nature 379:830-833.

Wang T, Xie K, Lu B (1995) Neurotrophins promote maturation of developing neuromuscular synapses. J Neurosci 15:4796-4805.

Wang X-H, Poo M-M (1997) Potentiation of developing synapses by postsynaptic release of neurotrophin-4. Neuron 19:825-835. 